\title{
DO BRAVO AO MANSO POR MEIO DE UMA LENTE: APROXIMAÇÕES IMAGÉTICAS À CRIAÇÃO DE BÚFALOS
}

\author{
Pedro Stoeckli Pires ${ }^{1}$
}

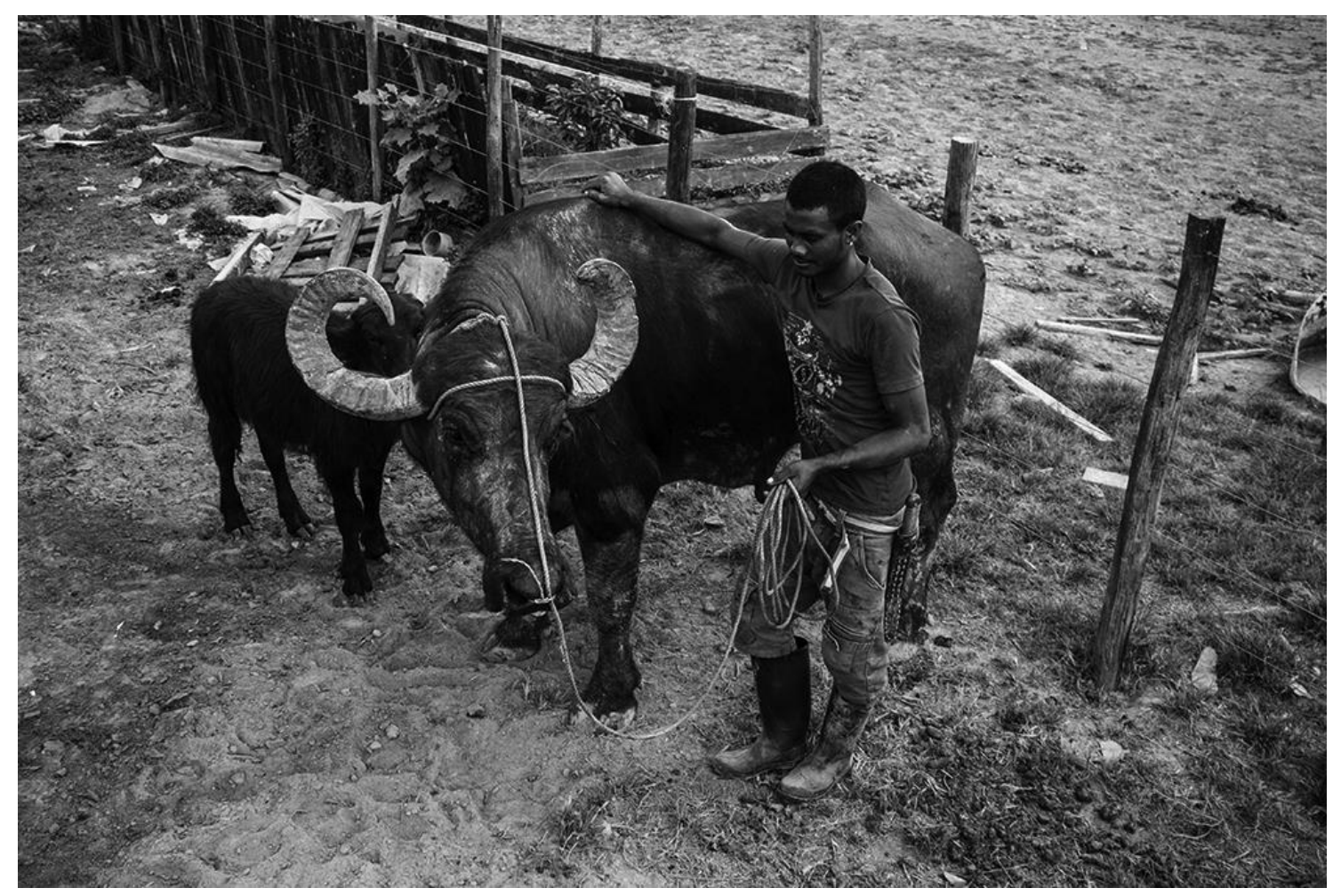

"A matéria-prima da fotografia é a face visível da realidade, que se encontra permanentemente em movimento" (Milton Guran, 2012: 7).

Eu estava há poucos dias na fazenda Paraíso, às margens do rio Araguari (Amapá), e havia conhecido alguns vaqueiros em uma grande festa na fazenda vizinha, a Campinho. Contudo, durante aqueles dias tive poucas oportunidades de observar algum evento diretamente relacionado com os búfalos e me sentia ávido por uma oportunidade de ver como os vaqueiros lidavam com aqueles animais que a pesquisa enfocava. Assim como em outras propriedades, na fazenda Paraíso, a maior parte do

\footnotetext{
${ }^{1}$ Universidade de Brasília, Brasil.
} 
gado fica espalhada pelo interior do terreno e os vaqueiros ${ }^{2}$ não têm contato constante com os búfalos. Nesse dia, eles haviam reunido parte do rebanho para o curral próximo da sede da fazenda para separar algumas vacas para ser ordenhadas na manhã seguinte.

Por volta das $17 \mathrm{~h}$ um garoto dentre os mais novos que estavam de passagem pela fazenda por conta da festa do dia anterior, e que eu não conhecia tão bem, laçou e montou um cavalo, sem a necessidade de o selar. Apesar de toda sua perícia, que me impressionou pela jovem idade do vaqueiro, os demais garotos comentavam todo o processo com constantes chistes, como se ele fosse desajeitado e não dominasse bem o cavalo. Como entenderia mais tarde, o tom jocoso sempre acompanha os vaqueiros quando assistem uns aos outros em ação, e é tão mais intenso quanto maior for o grupo.

Acompanhei a pé os garotos que se aproximavam do curral, enquanto o jovem vaqueiro tocava a manada de búfalos por trás da sede. Quando me aproximei o suficiente do curral, Seu Maguari, o vaqueiro mais experiente da fazenda, estava dentro da área cercada rodando seu laço em meio aos enormes búfalos que se movimentavam de forma a evitá-lo. A luz nessa hora do dia normalmente proporciona um amálgama de cores muito interessantes, com certo desvio para tonalidades avermelhadas, e esse dia não era exceção. Eu carregava a câmera a tiracolo e comecei a fotografar e a filmar, impressionado pelo tamanho dos animais e pela imagem do pequeno vaqueiro em meio ao gado, o que proporcionava uma boa noção de quão grandes e pesados são os búfalos.

Seu Maguari vestia uma camiseta amarela que gerava um forte contraste com os tons monocromáticos do barro seco sobre a cor preta dos búfalos. Maravilhado com o poder da imagem que a situação proporcionava, acabei por me esquecer de onde estava e dos possíveis perigos de estar próximo aos búfalos sem estar sobre um cavalo. Só me dei conta disso quando o feitor Zeca apareceu por trás de mim com os braços abertos e fazendo barulho para espantar uma vaca e dois bezerros que se aproximavam e que representavam um perigo em potencial, por poderem me "estranhar". Tive medo e me preocupei em não sair mais de perto dos demais vaqueiros, mesmo daqueles que tinham metade da minha idade.

\footnotetext{
${ }^{2}$ Ao longo desse texto me refiro às pessoas que trabalham em constante contato com o búfalo como vaqueiros. Inicialmente cheguei a usar a palavra peão, pois em alguns contextos esse é um termo comum. Contudo, eu logo notaria que no Amapá o termo peão tende a ser pejorativo, podendo ser também acionado de forma jocosa em determinados momentos. Assim, a "vaqueirice" se refere ao conjunto das tarefas que compõem o ofício do vaqueiro. Utilizo a palavra vaqueiro no gênero masculino, pois em minha experiência nesse contexto só conheci uma pessoa do sexo feminino que exercia a atividade da vaqueirice, mas mesmo essa pessoa preferia ser considerada vaqueiro.
} 
Eu havia encontrado búfalos antes, quando estava montado em um cavalo, mas encará-los no solo é uma situação totalmente diferente. Se seu peso e tamanho já são suficientemente imponentes, a situação se torna ainda mais espantosa pelo seu movimento em rebanho. Mais tarde eles me diriam que com esse gado não há tanto perigo, já que esse é o gado manso da fazenda, o que implica que há também o gado bravo. Mesmo assim, me dispus a ser mais atencioso à situação.

Instigado pela ideia de que há búfalos bravos, perguntava-me como um vaqueiro sabe reconhecê-los. Na verdade, pelo constante contato com os animais da fazenda, os vaqueiros sabem quais reses são domesticadas, como um deles me disse usando esse termo, isto é, mais dóceis e acostumadas à presença e ação humanas. O problema real, então, não é só saber separar búfalos bravos de mansos, mas saber interpretar quando um búfalo manso pode apresentar comportamento agressivo. Este foi, definitivamente, um dos temas que mais tentei explorar nas conversas sobre como entendem o comportamento dos búfalos, mesmo em momentos em que os vaqueiros lidavam com o gado considerado mais manso. Um búfalo, um vaqueiro certa vez me disse, "pode ser manso o que for que se estressa é de uma hora para a outra".

Em 1988 André Haudricourt e Pascal Dibie publicavam um artigo cujo o título era uma questão provocativa: o que sabemos dos animais domésticos? No texto, os autores afirmavam que muito se sabia sobre o comportamento de animais ditos selvagens, mas pouco tinha sido esclarecido até o momento sobre a influência que animais domésticos exerceram sobre os humanos e seus comportamentos e vivências (Hadricourt e Dibie, 1988). A pergunta é demasiadamente ampla para ter uma resposta simples, ou mesmo uma resposta, mas ela clama por maior desenvolvimento do conhecimento das relações entre humanos e animais.

Percorrendo temas sobre as relações entre humanos e animais, desenvolvi uma pesquisa etnográfica sobre vaqueiros, búfalos e o meio amazônico de várzeas onde se dá a relação entre eles. O trabalho de campo desta pesquisa foi realizado em Macapá, capital do estado do Amapá, e nas fazendas da região do baixo rio Araguari, próximas à sede do município Cutias do Araguari, onde se concentra a maior parte do rebanho bubalino do Amapá. A pesquisa foi feita nos meses de Abril de 2012, de Agosto a Novembro de 2012, e de Março a Maio de 2013 e resultou na tese de doutorado de título "Laços Brutos: Vaqueiros e búfalos no baixo Araguari - Amapá", defendida em novembro de 2015 no Departamento de Antropologia da Universidade de Brasília (UnB). Este artigo é composto por trechos e desdobramentos da tese. 
Cada um destes três componentes - vaqueiros, búfalos e o meio amazônico de várzeas - são simultaneamente e igualmente protagonistas daquilo que é chamado de bubalinocultura em campos de várzea amapaenses. Ou, como me refiro a ela em alguns momentos, a cultura dos búfalos, como algo que abarca desde a criação e a etologia do animal, até o comportamento dos humanos em relação a ele. ${ }^{3}$ É importante notar, também, o duplo sentido que o termo cultura pode ter, no sentido de criação do animal e de um complexo cultural, em um significado antropológico, em que o foco é sempre nas relações deste complexo.

O búfalo do pântano (Bubalus bubalis) é um animal ${ }^{4}$ de origem asiática que apresenta alta capacidade de adaptação a ambientes alagados (Marques, Lopes e Martinez, 2003), característica que fez com que os bubalinos fossem levados a diferentes regiões do mundo com objetivos comerciais, tal como ocorreu nos Estados Unidos, na Austrália e no norte do Brasil, a partir de 1895 (Marques, 2000). Cercada de características tanto positivas quanto potencialmente danosas ao meio ambiente, a criação de búfalos é apresentada como um complexo problema econômico, ambiental e social, o que se faz também verdadeiro no caso brasileiro.

Alguns setores da sociedade amapaense a veem como um potencial de desenvolvimento econômico para o estado, enquanto outros grupos a compreendem como demasiadamente danosa ao ambiente e aos recursos naturais amazônicos. Essa divergência gera debates e controvérsias políticas e jurídicas distintas, em diferentes esferas governamentais. Um dos objetivos da pesquisa era realizar panorama sobre a criação de búfalos no estado do Amapá, de modo a elucidar os principais aspectos e questões da cultura do búfalo e as diferentes concepções sobre os búfalos no estado. Para isso, abordei as políticas ambientais que englobam a área da pesquisa, a Reserva Biológica do Lago Piratuba - doravante Rebio do Labo Piratuba - e o posicionamento

\footnotetext{
${ }^{3}$ Em um comentário que Jean-François Bert (2009) faz sobre o termo "cultura" (e seu contraponto "civilização" na obra de Marcel Mauss), o autor ressalta que dentre os usos originais da palavra havia o conceito como a "alma vivente" de uma comunidade, em especial na tradição de estudos alemães. Nesse sentido, opto por falar em uma "cultura dos vaqueiros" em um sentido do conjunto de suas práticas cotidianas e do conhecimento e habilidades no desempenho destas. Por isso, mesmo usando o termo cultura, o aproximo desta ideia de civilização que Mauss utilizava, que associa objetos, comportamentos, classificações. O uso da palavra "cultura" tem também o objetivo de acompanhar o nome amplo pelo qual a atividade é conhecida, a "bubalinocultura".

${ }^{4}$ Acompanho a proposta de Tim Ingold de tratar humanos e animais sem partir do antropocentrismo inerente à dicotomia entre Sociedade e Natureza. Para isso, trato ambos como seres com consciência, volição e em processos de desenvolvimento em constante relação com o meio (Ingold, 1994 e 2000). Desse modo, seres como os búfalos são tratados na teoria de Ingold como animais não humanos, o que visa lembrar que humanos são também animais. Ressalto, então, que ao longo do texto deste artigo o termo "animais" é usado no mesmo sentido que Ingold propõe a partir da concepção de "animais não humanos".
} 
da atual gestão da Rebio em relação às populações que vivem dentro e próximas à área de preservação. Assim, busquei qualificar as posições de diferentes grupos envolvidos com a bubalinocultura no Amapá, bem como apresentar como essas posições são formadas a partir de relações específicas que estes grupos desenvolvem com os búfalos.

Portanto, esta pesquisa etnográfica pode ser pensada em dois campos distintos: 1o acompanhamento de debates, audiências públicas e reuniões entre ambientalistas, técnicos e pecuaristas, que se relacionam com o búfalo por meio de instrumentos de mensuração, planilhas, cifras, conceitos, monitoramentos e imagens aéreas e; 2- o trabalho de campo registrando as práticas dos vaqueiros e os objetos técnicos com que lidam com os búfalos, como laços, cavalos, barcos, cercas e terçados (facões). Em ambos os casos, as formas de aproximação dos búfalos passam eminentemente pela leitura e feitura de imagens, que abordo neste artigo.

\section{Uma controvérsia expressa em imagens}

A Reserva Biológica (Rebio) do Lago Piratuba, locus central deste estudo, está localizada no extremo leste do estado do Amapá, abrangendo parte dos municípios de Tartarugalzinho e Amapá, na região do baixo curso do rio Araguari e do cabo Norte. Com uma área total de 392.469,1100 hectares, a Rebio é administrada, desde 2007, pelo Instituto Chico Mendes de Conservação da Biodiversidade (ICMBio), autarquia federal vinculada ao Ministério do Meio Ambiente, responsável pela gestão das unidades de conservação federais em virtude da divisão do Instituto Brasileiro do Meio Ambiente e dos Recursos Naturais Renováveis (IBAMA). ${ }^{5}$

A Rebio do Labo Piratuba é constituída majoritariamente por ecossistemas de várzea. Como descrevem Daniel et al (2001: 384), estes ecossistemas são caracterizados por variações de maré duas vezes ao dia por períodos de até seis horas ou mais. As grandes áreas de várzeas são amplamente inundadas algumas vezes por mês, durante as marés mais elevadas associadas às luas cheias e novas. Notadamente, as áreas de várzea amapaenses são marcadas por regimes dinâmicos e pela mutabilidade de rios e igarapés, que podem surgir ou fechar de uma estação para outra (Santos, 2006; Raffles, 2002).

\footnotetext{
${ }^{5}$ A unidade foi criada por meio do Decreto Federal n ${ }^{\circ} 84.914$ de 16/07/1980 e teve seus limites alterados pelo Decreto Federal nº 89.932 de 10/07/1984.
} 
Este é o caso de uma das principais atrações da região. O rio Araguari se tornou nacionalmente famoso pelo fenômeno da Pororoca, um fenômeno causado a partir de um encontro entre a maré enchente e a vazão do rio. A Pororoca pode gerar ondas que chegam até $3 \mathrm{~m}$ de altura e percorrem vários quilômetros da extensão do rio. $\mathrm{O}$ fenômeno tem marcada importância histórica e mítica, mas recentemente as ondas da Pororoca têm perdido força. Em julho de 2015, uma matéria televisiva do maior jornal de exibição na rede aberta noticiou o fim do fenômeno, sustentando o argumento de que a criação de búfalos nas fazendas às margens do Araguari teria causado a diminuição da vazão da água do rio. ${ }^{6}$

As variações ambientais causadas pela criação de búfalos são bem conhecidas e relatadas. Dentre as diferentes características dos búfalos, algumas são descritas por ambientalistas como de alto potencial de impacto ambiental. Como enfatizam Collier et al (2011), quando em altas densidades populacionais, o búfalo causa mudanças intensas no ambiente, como a formação de seixos e a destruição de vegetações em razão de seu deslocamento. Nesse mesmo sentido, Bisaggio et al (2013: 245-6) afirmam que em ambientes tropicais os rastros deixados por manadas de búfalos destoam da vegetação adjacente:

Como os búfalos são animais gregários, de grande massa corporal e possuem o hábito de sempre utilizarem as mesmas trilhas e caminhos, seus vestígios são notoriamente maiores que os de outros herbívoros (...) como capivaras e cervídeos.

Desse modo, esses autores consideram que, além de modificarem o terreno, os búfalos tendem a competir por pastagens com espécies nativas, como os cervídeos. Outra característica destacada com frequência, não menos significativa, é que o búfalo pode apresentar perigo a humanos por seu potencial comportamento agressivo e territorialista, principalmente se há muito tempo sem contato com grupos humanos (Bisaggio, et al. 2013; Monteiro 2009). Por essas características, dentre outras, os búfalos são comumente descritos por ambientalistas como uma "praga" que causa danos no terreno. Isso porque no local onde búfalos se alimentam e se deslocam a vegetação

\footnotetext{
${ }^{6} \mathrm{Na}$ matéria aparecem dois personagens importantes nesta pesquisa, a Chefe da Rebio, que acusa a criação de búfalos como um precursor das drásticas mudanças nas dinâmicas do rio Araguari, e o presidente da Federação de Pecuária do Amapá, que aponta outros fatores como determinantes do processo. De qualquer modo, são desdobramentos dos argumentos do debate apresentado no primeiro capítulo desta tese. Conferir "Pecuária pode ter causado fim da pororoca do rio Araguari", matéria exibida no Jornal Nacional no dia 10/07/2015. Disponível em: http://g1.globo.com/jornalnacional/noticia/2015/07/pecuaria-pode-ter-causado-fim-da-pororoca-do-rio-araguari-no-amapa.html (acessado 15/07/2015 - acessado em 18/07/2015).
} 
original e outros tipos de cultura dificilmente prosperam. Esse potencial de alteração do terreno é também descrito por pecuaristas e vaqueiros, sem, contudo, considerá-los um problema.

No estado do Amapá, as principais críticas à criação de búfalos nas regiões de várzeas vêm dos funcionários do Instituto Chico Mendes de Conservação da Biodiversidade, o ICMBio, que consideram a atividade extremamente danosa ao ambiente. As áreas de proteção brasileiras são regidas pela Classificação do Sistema Nacional de Unidades de Conservação no Brasil (SNUC), que define a categoria Reserva Biológica dentro do grupo de Unidades de Proteção Integral (Brasil, 2000). Nesta classificação, fica "inteiramente proibida a exploração ou o aproveitamento direto dos recursos naturais" (Ministério do Meio Ambiente, 2008: 18-20). Desta forma, as Reservas Biológicas (Rebios) têm como objetivo "preservar integralmente a biota e os demais atributos naturais existentes em seus limites, não permitindo interferência humana direta ou modificações ambientais". Por essas razões, estariam interditas a presença humana e de espécies estrangeiras à biota local (IBAMA, 2002), como são considerados os búfalos.

De acordo com relatórios técnicos feitos por técnicos do Ibama (Tomás, Tiepolo, \& Camilo, 2007), existe uma densidade extremamente alta de búfalos na Rebio do Lago Piratuba, especialmente no setor sul, ao longo do rio Araguari. Este diagnóstico advém de dois estudos de estimativa, um realizado em 2006 e outro em 2013, com a mesma equipe do trabalho anterior. A imagem a seguir é apresentada por técnicos do ICMBio como uma comprovação da existência de grandes rebanhos de búfalos no interior da Rebio. 


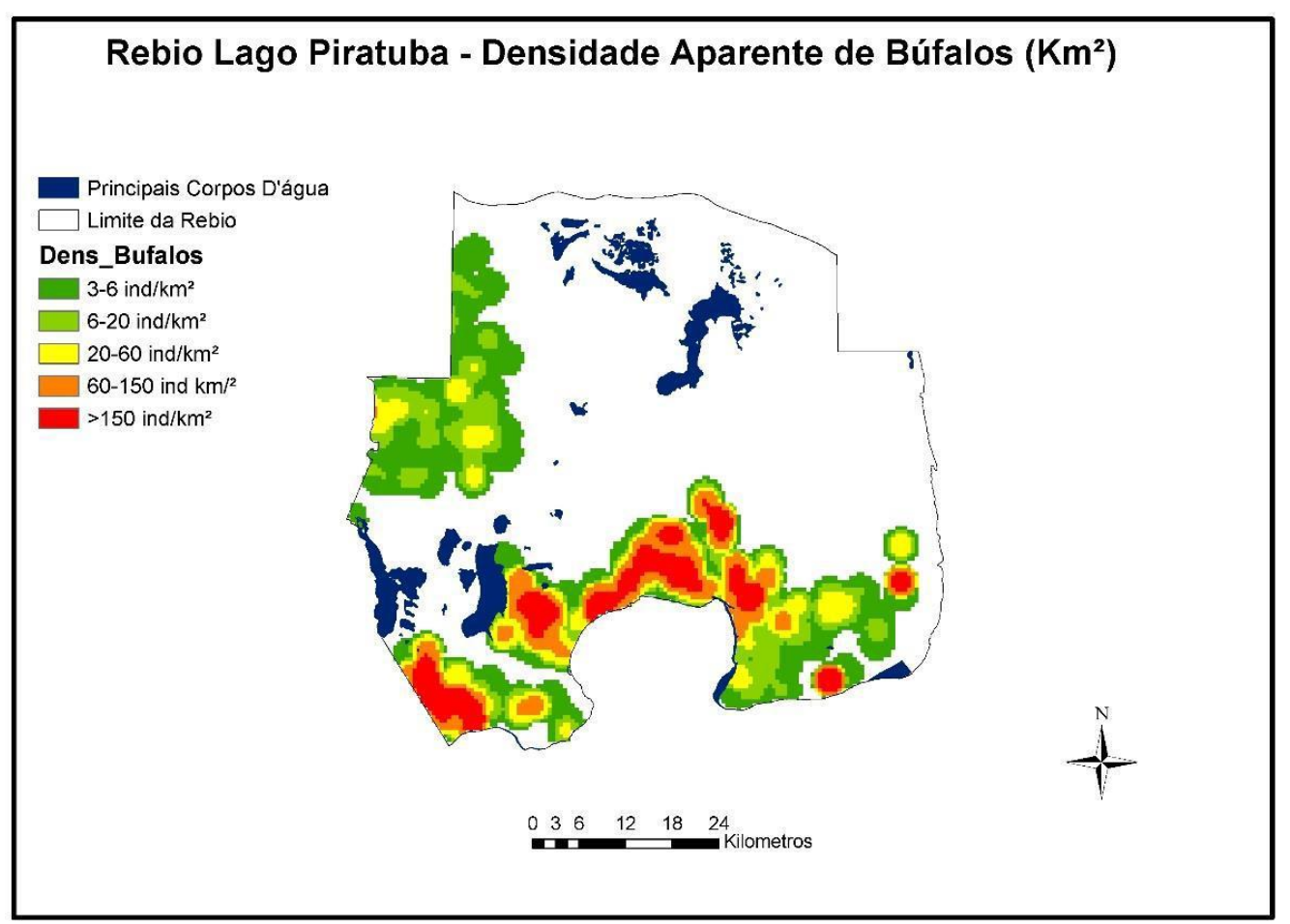

Figura 1: Zonas de concentração de gado bubalino na Rebio do Lago Piratuba em 2013. (Reproduzida com autorização a partir da apresentação realizada por técnicos do ICMBio).

Em conversas com Patrícia Pinha, Chefe da Rebio do Lago Piratuba/ICMBio, ela explica que trabalha com a área da Rebio há cerca de dez anos e durante esse intervalo já nota o quanto os campos de várzea já foram escoados e se tornaram mais secos, danos ambientais que ela atribui à ação do gado. Se antes a diferença dos campos durante as estações do inverno (chuvosa) e no verão (seca) era só o nível da água, ela argumenta que atualmente no verão os mesmos campos se encontram bastante secos. Apesar de reconhecer a influência de dinâmicas intercontinentais na região, como o El Niño e $L a$ Niña, em sua análise a pecuária está "acabando com a região" e "recortando" todo o território, menção aos seixos deixados pela movimentação do gado.

Tal como a maioria dos moradores da região com quem conversei, Patrícia vê os chamados "varadouros" como a principal razão da diminuição do volume de água escoado ao mar pelo Araguari. Em uma descrição da situação mais recente do rio Araguari, a chefe da Rebio do Lago Piratuba diz que esse escoamento pelos igarapés fez com que a foz do Araguari fosse assoreada "por completo", pois a vazão do rio diminuiu muito e, portanto, a água do mar entra com maior força no rio, trazendo enorme quantidade de sedimentos. Por isso, ela diz, a Pororoca já não ocorre mais no Araguari. 
Portanto, na análise dos gestores ambientais, esse conjunto de danos ou impactos ambientais são originados ou agravados pela bubalinocultura. Destes, uma das modificações mais imediatas é a alteração dos solos, como destacado. Em função de seu peso e tamanho, o búfalo é capaz de deixar pegadas com profundidades de mais de 10 cm e larguras variáveis, principalmente em terrenos úmidos (Santos, 2006; Monteiro, 2009). Por essa razão, Tomás, Tiepolo, \& Camilo (2007: 6) apontam como sinais visíveis da presença de bubalinos o aparecimento de canais, trilhas, vegetação alterada e águas barrentas.

Nas apresentações que fazem para tratar da questão dos búfalos dentro da Reserva, tanto em audiências públicas quanto em reuniões de negociação com pecuaristas e autoridades estatais, os funcionários do ICMBio inserem duas imagens (reproduzidas a seguir) que têm a intenção de demonstrar um contraste encontrado dentro da Reserva. A primeira (Figura 2) mostra uma vista aérea de uma manada em movimento e seixos criados a partir de sua tendência de se deslocarem em filas e seu peso corporal. Solos de áreas de várzea são formados a partir de sedimentos terciários e quaternários que são bastante sensíveis (Santos, 2006). A segunda imagem (Figura 3) visa representar um ideal de bioma não modificado pela ação antrópica e de animais de espécies exógenas.

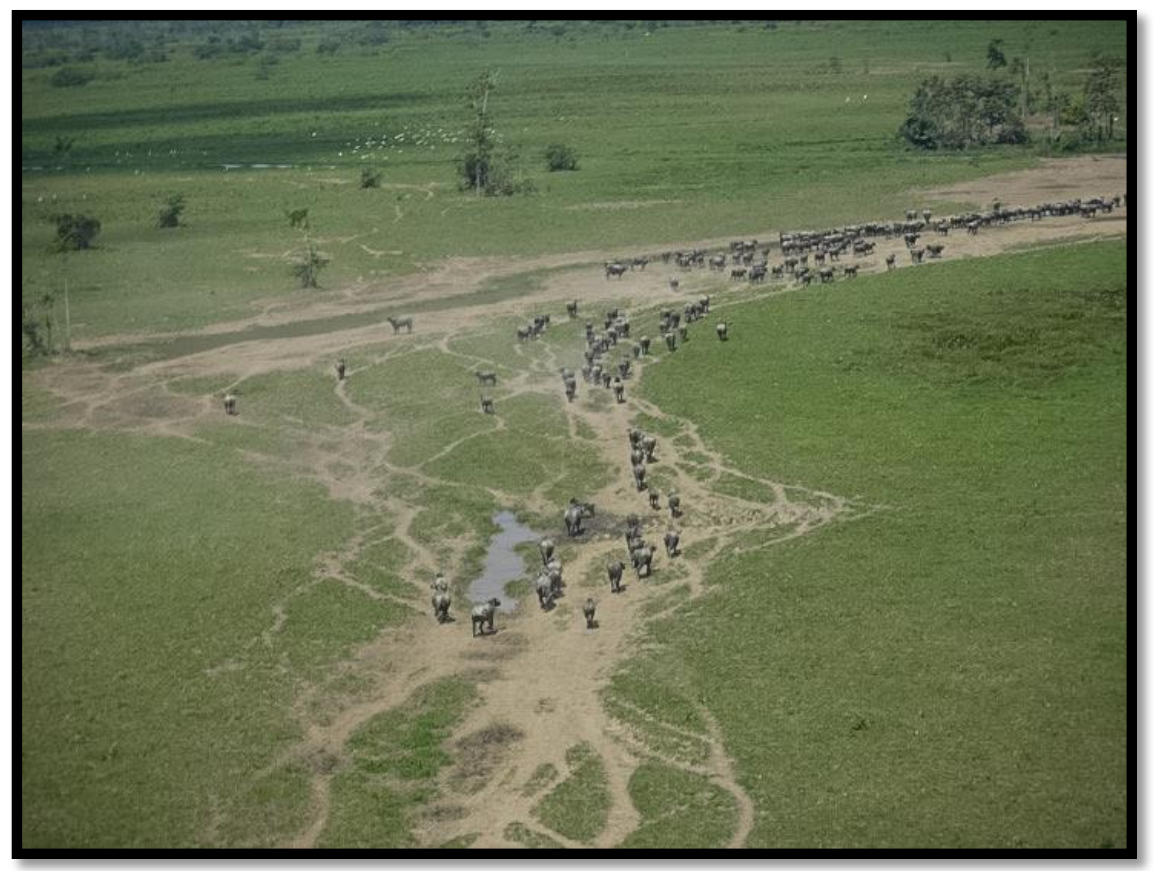

Figura 2: Movimentação de Búfalos dentro da Rebio do Lago Piratuba. Fonte: Acervo ICMBio - reproduzida com permissão. 


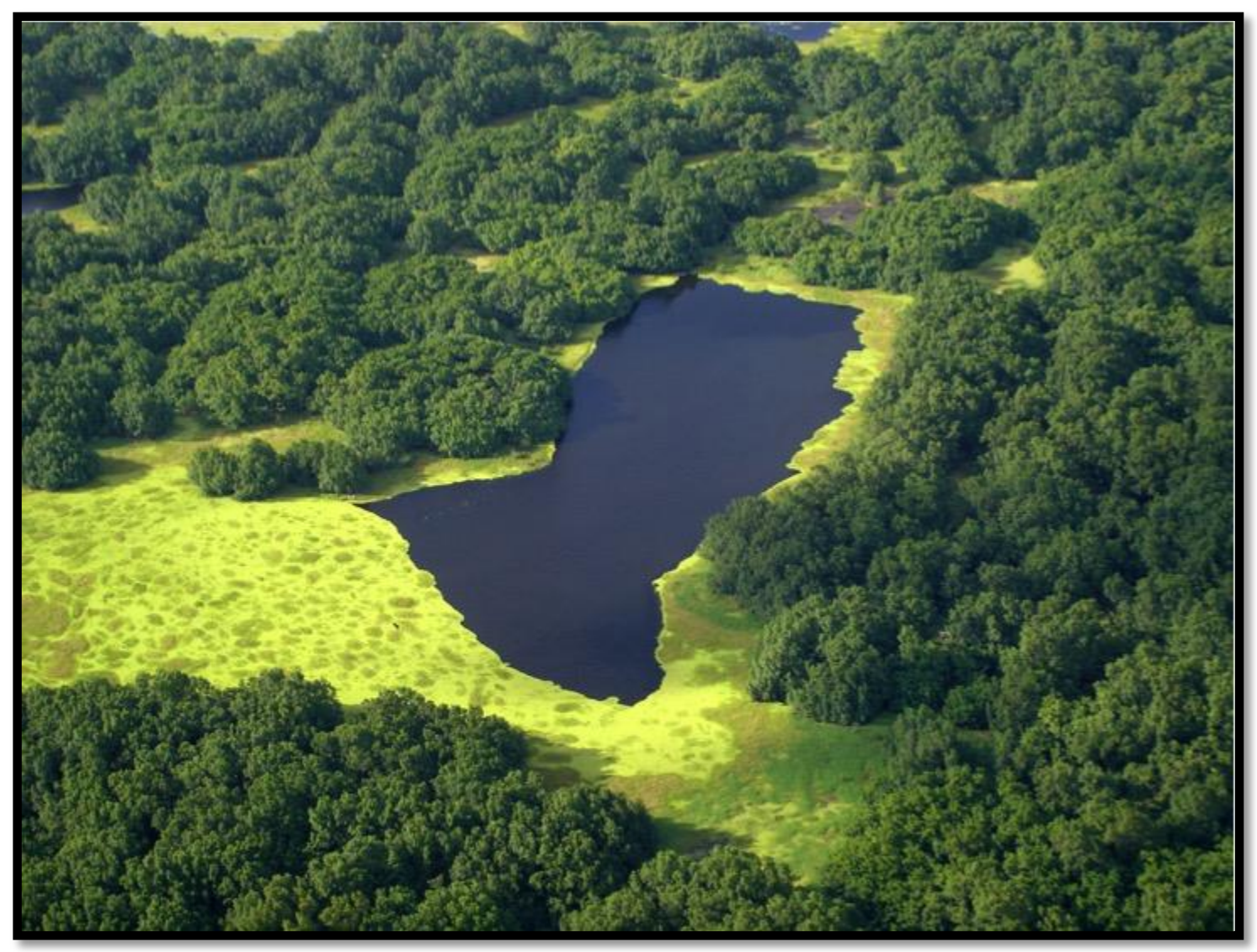

Figura 3: Paisagem ideal da Rebio do Lago Piratuba de uma perspectiva ambientalista Fonte: Acervo ICMBio - reproduzida com permissão.

Notícias recentes que focam principalmente o fenômeno da Pororoca vêm destacando as mudanças nos solos e nas dinâmicas hídricas na foz do Araguari, corroborando os argumentos sustentados pelo ICMBio de que os principais vetores dos considerados danos ambientais estão ligados à bubalinocultura. Além da matéria televisiva citada, outro estudo de monitoramento da base cartográfica ${ }^{7}$ reforçou 0 diagnóstico do assoreamento da foz do rio Araguari. Neste estudo, são interpostas duas imagens de satélite em uma mesma escala da foz do rio em dois momentos distintos, 2003 e 2014, reproduzida a seguir:

\footnotetext{
${ }^{7}$ Estudo feito pelo feito pelo Exército Brasileiro. Conferir: "Radar mostra antes e depois de rio onde existia a pororoca no Amapá”, divulgada em 27/07/2015, disponível em http://g1.globo.com/ap/amapa/noticia/2015/07/radar-mostra-antes-e-depois-de-rio-onde-existia-pororocano-amapa.html - acessado em 28/07/2015.
} 


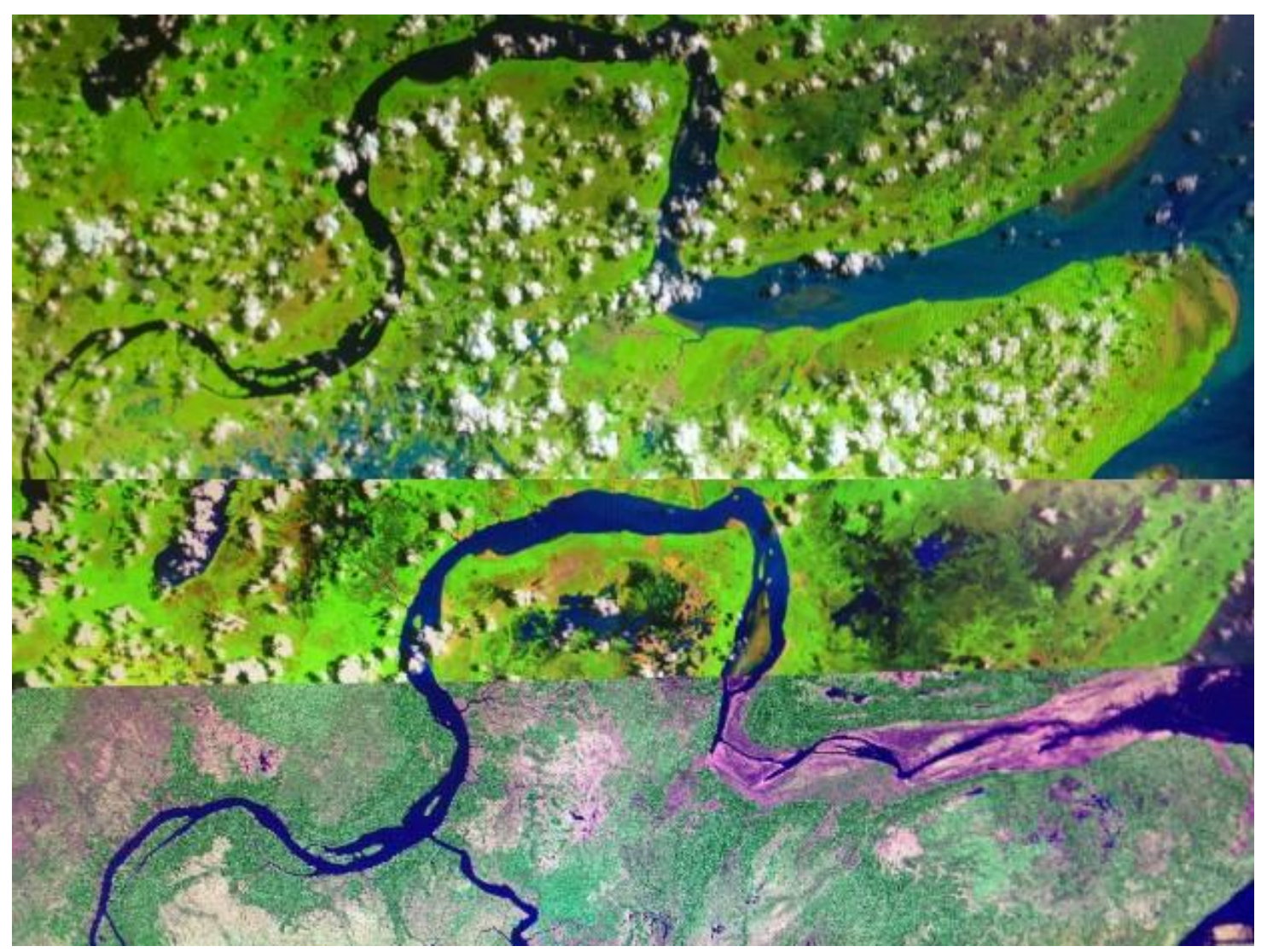

Figura 4: Imagens de satélite da foz do Araguari - 2003/2014.

De acordo com a matéria em que são divulgados os dados,

$\mathrm{O}$ aterramento causado pela abertura de canais ao longo do rio, somado à atividade pecuária nas margens causaram, segundo especialistas, o fim de um dos fenômenos naturais mais conhecidos do estado. Os registros fazem parte da primeira fase concluída da Base Cartográfica do Amapá feita pelo Exército Brasileiro. As imagens mostram em detalhes que restou apenas um pequeno canal de água no meio do rio Araguari, próximo ao Oceano Atlântico. As manchas lilases, por exemplo, representam o assoreamento. Os registros são de 2014 e foram feitos com radares.

As fotografias feitas no âmbito da atuação dos técnicos do ICMBio retratam uma situação de um "olhar de cima" a partir da perspectiva de alguém dentro de um helicóptero sobrevoando os campos de várzea. Este tipo de imagem leva o espectador a reflexões sobre as mudanças ocorridas na aérea e a interpretação dos impactos da criação de búfalos neste contexto. Nesse sentido, uma visão aérea proporciona compreender de outra maneira os efeitos do deslocamento dos búfalos a partir dessa escala, bastante diferente se vermos do chão os mesmos seixos e trilhas. Igualmente, o Instituto apresenta uma imagem formada a partir da observação e estimativa de 
rebanhos de búfalos. Por último, o monitoramento por satélite demonstra as modificações ocorridas nos solos e dinâmicas hídricas da foz do rio Araguari, uma imagem também usada como comprovação da ação da pecuária de búfalos e de seus efeitos na região.

Como afirma Bruno Latour (2001) em relação à produção de conhecimento científico, os cientistas dominam o mundo, desde que o mundo venha até eles sob a forma de inscrições bidimensionais, superpostas e combinadas. Essa mesma observação pode ser aplicada a pecuaristas, gestores ambientais, juízes e outros agentes. Ao buscar compreender as relações estabelecidas entre estes humanos com o animal búfalo, é importante considerar que estas se dão por meio de aparatos perceptivos desses atores, sejam eles normativas, documentos, cifras, medições, leis, conceitos científicos e, com frequência, mapas, imagens aéreas e de satélite, que se tornam pontos centrais nessa controvérsia e que, por isso, são elementos importantes da pesquisa etnográfica.

Se fica claro a centralidade que a produção de imagens científicas têm nas disputas em relação à criação de búfalos no baixo Araguari, há outro tipo de imagem que foi produzida durante o meu trabalho de campo que trouxe aportes importantes na compreensão da atividade do vaqueiro em seu trabalho com o búfalo.

\section{Uma atividade em movimento - imagem georreferenciada}

A atividade da vaqueirice, mesmo quando praticada em equipes (como nas fazendas médias e grandes), é, na maior parte do tempo, bastante individual, para não dizer solitária. Seja na manutenção de cercas ou no trajeto percorrido a pé, a cavalo ou em um "casquinho", o vaqueiro com frequência passa boa parte do tempo sem a companhia de outros humanos. É importante notar que, quando sozinho, perigos inerentes à sua atividade se tornam mais agudos e o vaqueiro deve ser cauteloso, pois, em caso de acidente, não poderá contar com a ajuda de "camaradas". Essa característica por vezes solitária da vaqueirice implicou em que muitas vezes não foi possível acompanhar o trabalho a ser realizado no dia, em especial quando este envolvia buscar o gado que havia se afastado muito da sede da fazenda. 
Uma parte importante e cotidiana na atividade de vaqueiro consiste em adentrar o território da fazenda para manejar o gado, juntar as reses e trazê-las para as áreas de pastagem ou áreas cercadas que ele julga mais adequadas na época, bem como separar vacas prestes a parir, animais doentes etc. Esse tipo de manutenção periódica tem o objetivo, também, de que o vaqueiro saiba sempre a localização dos animais da fazenda e a sua contagem, se há reses desaparecidas ou desgarradas do plantel.

De uma maneira geral, a bubalinocultura praticada de forma extensiva é marcadamente uma atividade em movimento. Igualmente, o manejo dos búfalos na região do baixo Araguari tem características que se adequam às especificdades de cada temporada. Como já exposto, a região amazônica amapaense é caracterizada por duas estações constrastantes ao longo do ano, a chuvosa, o inverno, e a seca, o verão. Essas duas estações implicam em diferentes comportamentos do gado. No auge da seca, por exemplo, o gado procura se refugiar de moscas hematófagas (sugadores de sangue), as chamadas Mutucas (Tabanidae). Quando a tarde começa a cair e as últimas luzes vão aos poucos se disspando, o gado se aproxima de locais em que ainda existam algum curso de água para fugir das moscas que se proliferam na mata.

Por outro lado, a maneira como os vaqueiros se movimentam pelo território depende também das diferenças entre estas estações. No período chuvoso do ano os animais passam mais tempo pastando no interior do território da Reserva e os vaqueiros trabalham monitorando o gado, juntando ou separando parte do rebanho, relocando-os no território da fazenda. Na pecuária de várzeas, enquanto na seca os vaqueiros na maioria do tempo montam cavalos, na época do inverno muitas vezes os vaqueiros percorrem o território "na maromba", ou seja, em cima de um casco (ou casquinho), denominação usada para uma pequena canoa, leve e de feitura simples, que comumente só suporta uma pessoa.

Essa movimentação pelo terreno é facilitada ou dificultada de acordo com dois tipos de terrenos contrastantes que os vaqueiros chamam de sujo e limpo. Nesse caso, o sujo se refere à mata densa, em contraste com o campo aberto, chamado de limpo. De igual maneira, no baixo Araguari o belo é descrito como o terreno dominado pela ação humana, enquanto a natureza intocada, ou, mais ainda, a que retoma o espaço que não é constantemente cuidado, é considerada mato, o oposto do terreno bonito.

No relatório técnico de Tomás, Tiepolo, \& Camilo (2007), os pesquisadores constatam que nesse contexto os bubalinos estão limitados a uma faixa que varia de 4 a $10 \mathrm{~km}$ de distância das margens do rio Araguari, o que coincide com relatos que obtive 
de vaqueiros. A partir dessas constatações, em minha segunda etapa de trabalho de campo, durante a estação de chuvas, busquei compreender melhor essa movimentação cotidiana do vaqueiro em busca do gado da fazenda. Para isso, utilizei um pequeno GPS da marca Garmin, modelo etrex, para registrar pontos e coordenadas dentro do território em que os búfalos se movimentam, que pode coincidir ou não com os limites da fazenda. Posteriormente os pontos foram processados no programa Google Earth, de onde são retiradas as imagens.

O trajeto a seguir no mapa foi registrado com esse aparelho pelo vaqueiro Nonô quando ele saiu da sede da Fazenda Helena Selva, ao lado da Comunidade Vai Quem Quer, para percorrer a área da fazenda e reunir os animais da fazenda em uma nova "malhada", durante a época chuvosa, na data de 30 de março de 2013, no período da manhã.

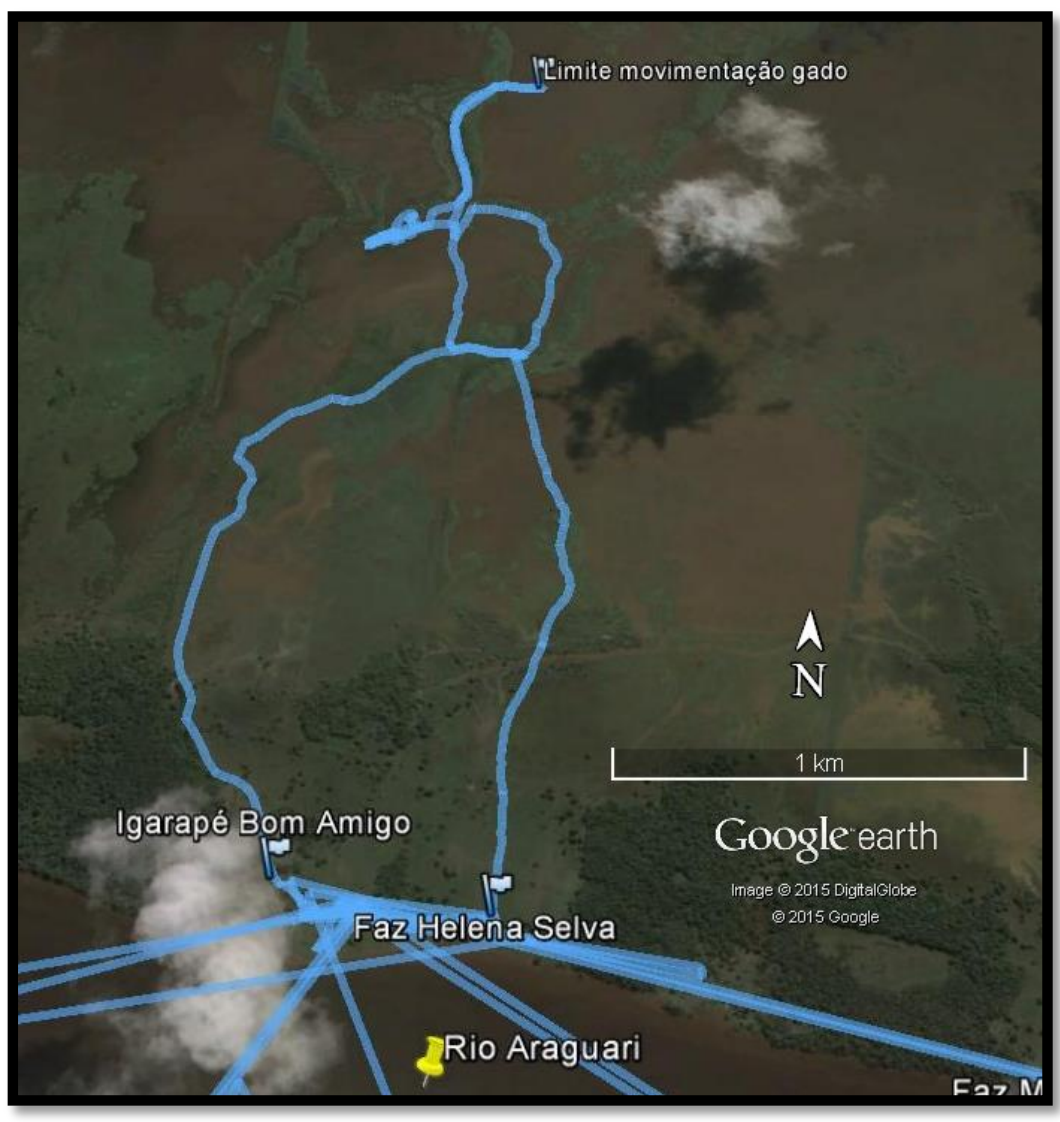

Figura 5: Movimentação do vaqueiro em busca do gado (Faz. Helena Selva). 
A imagem e o trajeto mostram que o vaqueiro percorreu a área da fazenda delimitada em suas laterais por cercas e matas. Como é comum ocorrer, em especial nas temporadas alagadas, o trajeto para o interior do território da Rebio neste dia foi percorrido a pé, a cavalo e em um "casquinho", acionando três modalidades de deslocamento de acordo com a condição do terreno. Na imagem o vaqueiro partiu em busca do gado pela linha lateral da direita, que é marcada pelo limite da fazenda Helena Selva, demarcada por uma cerca. Essa cerca segue por alguns quilômetros, quando o vaqueiro começou a se movimentar em cima de um "casquinho" por igarapés até o ponto mais alto do registro da movimentação. De lá, Nonô começa seu trajeto de volta para a sede da fazenda, reunindo o gado sem deixá-lo dispersar.

Em sua análise da percepção do deslocamento pelo meio, James Gibson (1979: 36) observa que o terreno sobre o qual os seres se movimentam raramente são ordenados, como são os espaços alterados pela ação humana. Nesse sentido, para Gibson ambientes desordenados proporcionam locomoção por meio de suas aberturas, concepção que descreve bem o que ocorre na bubalinocultura extensiva no baixo Araguari. Para enriquecer este argumento em outro sentido, busco inspiração na teoria de affordance de Gibson, uma tentativa de melhor compreender como os seres sencientes percebem o ambiente em que estão inseridos (Gibson, 1979).

As ideias gibsonianas inspiraram abordagens que acionam essa perspectiva ecológica para melhor compreender as relações entre seres humanos e não-humanos (Ingold, 2000). Para Gibson, todo animal é, em algum nível, um ser que age e percebe. Desse modo, o autor considera como ambiente o meio ao redor desses seres que percebem e agem, os animais, e que as palavras animal e meio ambiente fazem um par inseparável: um não poderia existir sem o outro (Gibson, 1979: 7-8). Assim, o ambiente de animais e homens é aquilo que eles percebem, não necessariamente o mundo descrito pela física, geografia ou alguma outra área de conhecimento ou perspectiva específica.

Mais que isso, o ambiente proporciona um meio pelo qual o ser age. Nesse sentido, o ambiente propicia, oferece (affords) abrigos, objetos, caminhos, desafios, perigos, comida, outros seres, predadores etc. ${ }^{8}$ São essas "ofertas da natureza, essas possibilidades ou oportunidades" que Gibson denomina através do neologismo de affordances (ibid.: 18). Este é, assim, um conceito que conecta tanto ambientes quanto

\footnotetext{
8 "The affordances of the environment are what it offers the animal, what it provides or furnishes, either for good or ill” (Gibson, 1979: 127 - ênfase no original).
} 
comportamentos, em que os ambientes existem em relação aos potenciais corporais físicos dos seres (ibid.: 129).

Partindo de inspiração semelhante, Ingold (2000) propõe entender a ação humana e não humana a partir da constante interação do organismo-pessoa em um ambiente ou mundo vivo, o que ele chama de dwelling perspective, a perspectiva do habitar. Em contraste com uma descrição estática do ambiente (landscape, em inglês), Ingold (2000: 154) propõe a noção de taskscape para designar um padrão de atividades de habitação. Nesse sentido, assim como a paisagem remete a uma série de recursos e características, o taskscape seria uma série de atividades relacionadas que são efetuadas por meio de movimentos, ponto constamente lembrado por Ingold (ibidem: 195-7). E para o autor, estes movimentos não necessariamente irão derivar em algo acabado, um ponto final:

... as atividades que compõem o taskscape são intermináveis, a paisagem nunca está completa: nem 'construída' e nem 'não construída', está perpetuamente em construção. É por isso que a dicotomia convencional entre os componentes naturais e artificiais (ou 'feitos pelo homem') sobre a paisagem é tão problemática (Ingold, 2000: 199).

Acredito que essas abordagens contribuem com pontos importantes para compreender os trajetos percorridos pelos vaqueiros em suas atividades, que, por sua vez, são também estabelecidos pela movimentação dos rebanhos de búfalos em sua busca por pastos, áreas de descanso e água. Neste caso, o acesso à movimentação do vaqueiro pela vasta área da Rebio e sua circulação pelos campos de várzeas em busca dos búfalos podem ser melhor visualizados com a produção de um tipo de imagem específica, a georreferenciada.

Se até aqui apresentei dois tipos de imagens que foram centrais na pesquisa etnográfica sobre a criação de búfalos na região do rio Araguari, as imagens científicas dos ambientalistas e a imagem georreferenciada do trajeto do vaqueiro em busca dos búfalos, passo agora a um tipo de imagem bastante presente nas pesquisas de campo antropológicas, a imagem fotográfica. 


\section{A inserção etnográfica com uma câmera}

No início de minha pesquisa de campo eu logo iria descobrir que a comunidade do baixo Araguari é constituída por relativamente poucas pessoas, e que a presença de alguém de fora certamente não passa despercebida. Na região do baixo Araguari, como em outros locais, pouco se sabe sobre o que é ser um antropólogo. Mas muitos, senão todos, sabem bem o que é uma câmera e o que resulta da presença do equipamento. Em Cutias do Araguari, cidade porta de entrada para a região em que fiz minha pesquisa, eu me apresentava como pesquisador. Mesmo se raramente portei a câmera fotográfica a tiracolo, fui com frequência interpretado como alguém que iria "filmar os búfalos". Creio que isso ocorreu, em parte, porque pessoas de fora da região que aparecem por lá na época em que fui pela primeira vez (o inverno) são imediatamente associadas ao turismo para ver a Pororoca do rio Araguari.

Como planejado, desci o rio na embarcação administrada pela prefeitura de Cutias, que sai de Cutias pela noite e amanhece próxima à foz do Araguari. O barco vai bastante cheio, com várias redes sobrepostas umas às outras. Logo no início dessa viagem, alguém alertou que um dos passageiros havia caído no rio. O comandante desacelerou a embarcação e um tripulante foi em uma lancha voadeira que fica acoplada ao barco principal para procurar pelo suposto náufrago. Após muito rebuliço, descobrimos que se tratava de um alarme falso, embora o perigo desse tipo de acidente seja bem real. Desisti de tentar dormir com os primeiros raios de luz da manhã, mas fui recompensado pelo belo visual das fazendas e matas às margens do rio banhadas pela alvorada.

A ocasião do alarme em falso ajudou a iniciar um clima de conversa mais generalizado na lancha. Conversei com um policial militar e um professor de Cutias, ambos descendentes de moradores da região que diziam não visitar suas propriedades há muito tempo. Conversamos sobre a festa no dia seguinte na Fazenda Campinho, organizada pelos filhos do proprietário para reunir a comunidade do baixo Araguari. Pensei que seria uma boa ocasião acompanhar um encontro desses, o que se provou verdadeiro. A fazenda Campinho, como me disseram, é considerada de pequeno porte na região. Com um rebanho pequeno, com poucas dezenas de reses, é de propriedade de um pequeno pecuarista criado no baixo Araguari que vive da bubalinocultura e do queijo que produz em determinadas épocas do ano. 
Armei minha rede e meu mosquiteiro do melhor jeito que pude na área externa da casa. Logo percebi que o cheiro de guano de morcegos e o barulho dos mesmos seriam uma constante nas fazendas do baixo Araguari. No dia seguinte, por volta das seis horas da manhã, os vaqueiros Chiquinho e Vadico já estavam de pé e preparavam seus cavalos para a corrida, levando-os à margem do rio para banhá-los e limpá-los. O prêmio para o vencedor da corrida seria de R \$1200,00 e um engradado de cerveja, o que gerava bastante expectativa. Eram esperados cerca de 10 cavaleiros na corrida, apesar de que ouvi mais tarde que os organizadores esperavam contar com pelo menos 20 corredores.

Os encarregados do som seriam Zeca e seu filho Jefferson. Logo cedo eles testavam sua aparelhagem, composta de uma mesa de som, um dvd player e várias caixas de som. Seguimos cedo para a Campinho para preparar os aparelhos e antes de $8 \mathrm{~h}$ da manhã os som já tocava forte nos alto falantes. Os pequenos barcos rabetas e lanchas maiores começariam logo a chegar, sempre lotados de pessoas e bens pessoais, como roupas (afinal todos pretendiam ficar até o baile da noite). Por volta de $11 \mathrm{~h}$ da manhã ocorreu a primeira prova da corrida de cavalos. $\mathrm{O}$ percurso foi delimitado no extenso campo aberto à margem do rio, que dá nome à fazenda, e era de aproximadamente 500 metros. Seriam 3 baterias com 3 corredores em cada e uma final com os três vencedores de cada corrida. Além do prêmio de $\mathrm{R} \$ 1.200,00$ ao vencedor, o segundo e o terceiro melhores receberiam $\mathrm{R} \$ 500,00$ e $\mathrm{R} \$ 300,00$ respectivamente, totalizando $\mathrm{R} \$ 2000,00$ em dinheiro. Cada participante havia pago $\mathrm{R} \$ 100,00$ para se inscrever.

Era efetivamente o meu primeiro dia com os moradores do baixo Araguari, então poucos me conheciam, apesar de que boatos sobre pessoas de fora correm rapidamente. Ainda pouco familiarizado com as pessoas ali, utilizei da câmera fotográfica como subterfúgio, mas também como uma maneira de me aproximar das pessoas, que se mostravam abertas a serem fotografadas. Quando começaram as corridas, fotografei alguns cavaleiros e resolvi também filmar um pouco. Na última bateria de corridas, que decidiria o cavaleiro campeão, me posicionei no final do percurso, marcado por uma antiga cerca da fazenda. Eu pretendia fazer uma tomada clássica de corridas, filmando o momento em que os cavaleiros passariam a linha de chegada. Foi uma decisão despretensiosa, mais para me distrair do que qualquer outra coisa, mas acabei assumindo um papel não planejado por conta do desfecho da corrida. 
Os finalistas eram Devaldo, filho do dono da fazenda Campinho e vaqueiro da fazenda Santa Rosa, propriedade maior localizada mais acima do rio, e outros dois cavaleiros do Bailique, arquipélago próximo à região. Na largada, Devaldo e seu cavalo saíram bem à frente dos outros dois cavaleiros. Mas, em um final digno de páreos profissionais, um dos cavaleiros alcançou o cavalo de Devaldo no último segundo, gerando um aparente empate e muita comoção. Não havia um juiz designado para a corrida, e próximos a mim estavam cerca de seis homens partidários dos diferentes cavaleiros. Assim que ficou claro que não houve nitidamente um vencedor, eles correram em minha direção e pediram, alvoroçadamente, para ver a filmagem na câmera. Exaltado, um deles chegou mesmo a tomar a câmera de minha mão para ver melhor o pequeno visor que mostrava os poucos segundos da decisão.

E foi assim que assumi, sem a menor intenção, o papel de árbitro ou de photofinish improvisado da corrida. Passei e repassei, incontáveis vezes, a curta cena para muitas pessoas na festa, o que me ajudou a conhecer muitas delas. Quadro por quadro, indo e voltando, o que pouco esclarecia a respeito do ganhador, pois um cavalo estava mais à frente e outro com o pescoço mais inclinado. Se houve um ganhador, foi por poucos centímetros, ou por um triz, como se diz. Por isso, um lado da disputa alegava que o cavaleiro de camisa branca era o vencedor, enquanto outras pessoas diziam que o cavaleiro de camisa vermelha realmente ultrapassou no último segundo. Sem conhecer muito bem a dinâmica das relações ali, quando questionado qual era a minha opinião eu me esforçava ao máximo para não tomar partido, como fazem bem os mineiros nesse tipo de situação.

A bem da verdade, até hoje não sei quem foi realmente o vencedor. Mas o fato é que essa corrida aconteceu em agosto de 2012 e até o fim de meu trabalho de campo, em maio de 2013, eu seria vez ou outra perguntado sobre a filmagem e quem foi o vencedor da corrida. ${ }^{9}$ Trago esse relato, pois acredito que ele retrata bem o estilo de etnografia que marcou esta pesquisa. Como bem observou Anthony Seeger (1980: 25):

\footnotetext{
${ }^{9}$ Süssekind (2010: 47) narra que a câmera fotográfica também ajudou a sua inserção no trabalho de campo: "Durante a estadia na fazenda, eu carregava sempre uma câmera, e várias vezes tinha filmado ou fotografado o trabalho deles com o gado. As imagens preferidas eram aquelas nas quais apareciam laçando (na fazenda, as fotos e filmagens eram assistidas com interesse no Galpão, e os peões se divertiam com os erros dos outros e pediam para eu gravar quando achavam a cena ou a foto boa)."
} 
O material etnográfico sobre o qual a Antropologia trabalha é quase sempre o resultado da atividade singular do pesquisador no campo, num momento especifico de sua trajetória pessoal e teórica, de suas condições de saúde e do contexto dado, e essa atividade e exercida sobre um grupo social que se encontra num certo momento de seu próprio processo de transformação.

O fato de eventos singulares marcarem como é feito o trabalho de campo é algo bem descrito na literatura antropológica (Cf. Geertz, 1973). Em meu caso, a presença do equipamento fotográfico teve implicações no modo como meus interlocutores passaram a se relacionar comigo. Além da produção textual, em cadernos de campo, o registro audiovisual em fotografia e vídeo de práticas da cultura do búfalo tem um papel central na construção do argumento desta pesquisa, o que explico a seguir.

\section{Do Bravo ao Manso por meio de uma lente}

A proposta de uso da fotografia e do vídeo durante a pesquisa certamente não é nova e remete às origens da antropologia (Samain, 1998; Guran, 2012). ${ }^{10}$ Contudo, ressalto que a utilização da câmera durante a pesquisa de campo é, além de um recurso metodológico, um aporte epistemológico, pois a presença do equipamento de registro de imagens em campo estabelece relações diferenciadas entre o pesquisador e as pessoas e instrumento se torna um "produtor de imagens mas também de questões" (Sautchuk, 2007: 23 e 2012). ${ }^{11}$

Um desdobramento desse aspecto que me pareceu negativo à produção de conhecimento antropológico é que em determinado momento de minha pesquisa de campo me encontrei de certa forma viciado em produzir imagens. Parecia-me que tudo que era importante para a pesquisa deveria ser registrado em vídeos e fotos, e às vezes eu achava difícil observar algo sem ter comigo a câmera. Em várias das atividades que acompanhei não havia uma anunciação explícita de que algo estava para acontecer não havia muito aviso prévio do que estava por vir, fosse sair para o campo, ir buscar as vacas para serem ordenhadas ou até mesmo abater uma rês. Os vaqueiros pareciam saber o que deveria ser feito e não anunciavam, por isso, cada etapa. Nessa coordenação

\footnotetext{
${ }^{10}$ É notável que o uso de imagens como registro etnográfico já aparecesse no clássico estudo de Malinowski (1976 [1922]).

${ }^{11}$ Ressalto que a discussão que faço aqui se limita à fotografia como um método de pesquisa etnográfica, sem ter pretensões de entrar no amplo debate da fotografia na antropologia visual e tampouco no campo das artes. Isso, no entanto, não é afirmar que aspectos estéticos e simbólicos não sejam importantes à discussão do uso de imagens em pesquisas antropológicas.
} 
sutil e não verbalizada das ações, já perdi momentos decisivos e o fio da meada mais de uma vez. Por isso, eu procurava manter a câmera comigo sempre no ponto de fotografar algo.

Do mesmo modo, por usar uma câmera digital moderna, o mesmo aparelho poderia ser usado para filmar ou fotografar, e não foram raras as vezes que essa possibilidade me deixava em um impasse sobre em que suporte registrar um fato, correndo o risco mesmo de perdê-lo. ${ }^{12}$ Sobre isso, procurei lembrar da observação de Malinowski em suas instruções sobre o trabalho de campo (1976 [1922]: 35), quando afirma que às vezes é necessário deixar de lado o papel e a caneta (ou outro instrumento de registro) e vivenciar o fato de modo mais direto.

Em excelente reflexão sobre a produção de imagens na pesquisa de campo antropológica, Milton Guran propõe o binômio "fotografar para descobrir e fotografar para contar" (Guran, 2012) identificando duas finalidades distintas, a saber, a fotografia feita com objetivo de se obter informações e a fotografia feita para demonstrar ou enunciar conclusões:

\begin{abstract}
A fotografia produzida "para descobrir" corresponde àquele momento da observação participante em que o pesquisador se familiariza com o seu objeto de estudo, e formula as primeiras questões práticas com relação à pesquisa de campo propriamente dita (...) a fotografia "para contar" corresponde ao momento em que o pesquisador compreende e, de certa forma, domina o seu objeto de estudo, podendo, portanto, utilizar a fotografia para destacar com segurança aspectos e situações marcantes da cultura estudada, e desenvolver sua reflexão apoiado nas evidências que a fotografia pode apontar (Guran 2012: 4).
\end{abstract}

$\mathrm{Na}$ mesma linha de argumentação, Guran afirma que ao captar o inesperado e o imprevisível a fotografia pode levar a novas possibilidades para a compreensão e a absorção de aspectos abordados na pesquisa. Acredito que isso descreve bem o papel central que a produção imagética tem em minha pesquisa de campo. Afinal, foi ao me deter longamente em uma imagem específica que foi possível elaborar o título e um dos conceitos centrais de minha pesquisa de doutorado, episódio que pode ser caracterizado como o que Strathern (1999) chamou de um "momento etnográfico". No caso, foi a partir de uma imagem que teve a gênese de um dos conceitos centrais desta pesquisa,

\footnotetext{
${ }^{12}$ Esse foi o caso que me ocorreu quando eu observava um garrote laçado pelos chifres lutando contra a força da corda que lhe continha. Eu estava muito próximo a ele, mas protegido por uma cerca de madeira. Ou pelo menos eu acreditava estar protegido, pois ao agitar sua cabeça para tentar se livrar da amarra, o garrote atingiu a cerca de madeira, que quebrou com surpreendente facilidade. Eu estava mudando o modo da câmera de filme para fotografia, e perdi a chance de registrar a cena, que certamente foi expressiva.
} 
expressos na ideia de "Laços Brutos", que busca evocar, ao mesmo tempo, pelo menos três esferas de significado que acredito serem centrais na compreensão da cultura do búfalo.

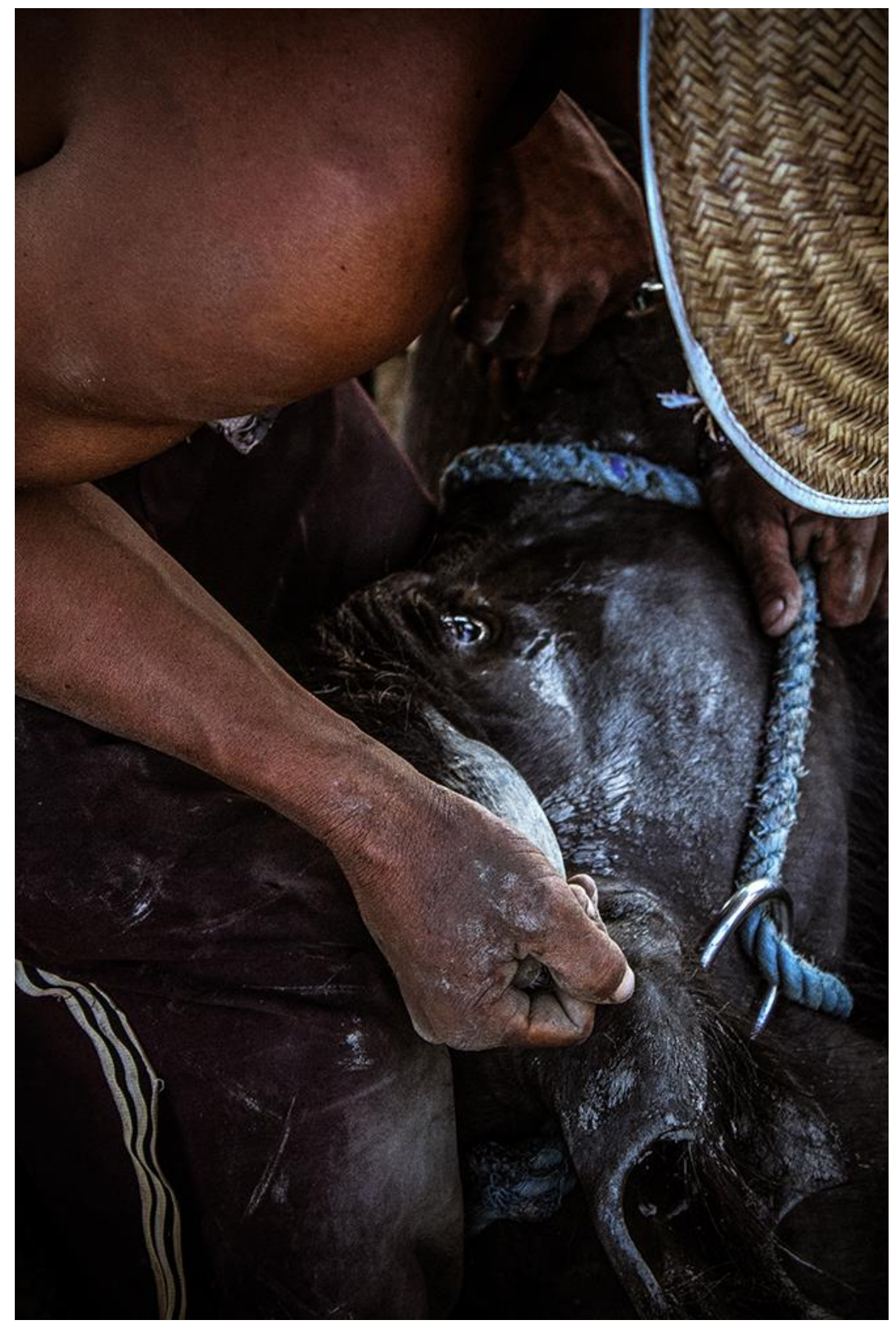

Figura 6: Laços Brutos. 
De certa maneira, a importância do sentido visual acompanha também a centralidade que é "ver" o gado em uma cultura de vaqueirice. Nesse sentido, tendo a concordar com Süssekind (2010: 41) quando ele afirma que os vaqueiros 'lidam' com o gado de uma forma predominantemente visual, pois eles constantemente se referem a cores da pelagem e detalhes físicos de cavalos e bovídeos para os diferenciarem. Ou, como escreveu Grasseni (2004: 42), como um etnógrafo e antropólogo visual, é necessário aprender a olhar para as vacas para poder acessar parte da visão de mundo dos criadores de gado. Em um trecho de meu caderno de campo, anotei o seguinte sobre uma conversa ocorrida na fazenda Campo Novo:

\begin{abstract}
Ao receber a visita de vaqueiros de outra fazenda, todos conversam sobre os cavalos que estão mais à frente da casa principal. Tento acompanhar os comentários, mas para mim [os animais] parecem muito uns com os outros. Os vaqueiros os diferenciam por pequenas características e se referem a eles por cores, o que me deixava ainda mais confuso.
\end{abstract}

Se antes mesmo de chegar ao local definido para meu trabalho de campo eu levava comigo a proposta de uma análise visual do modo de vida do vaqueiro amazônico, ao chegar nesse contexto a produção de imagens se tornou mesmo algo necessário. Se para compreender a atividade com o búfalo também é importante abordar os trajetos e as formas de sociabilidade com outras pessoas na região, a entrada nesse contexto por meio da imagem - como photofinish, fotografando as pessoas estimulavam conversas sobre o gado e sobre aspectos da vida na vaqueirice que se constituíram como uma chave de aproximação a este universo.

No que concerne a inserção do pesquisador no contexto a ser estudado, a feitura de imagens, tanto fílmicas quanto fotográficas, modifica a relação com as pessoas que o recebem, o que abordei alhures (Stoeckli, 2011a). Esse tipo de postura durante a pesquisa de campo é relativamente bem descrita. Em uma pesquisa em uma comunidade rural nos Estados Unidos, Dona Schwartz via o ato de tirar fotos das pessoas ${ }^{13}$ uma maneira de conectar-se a elas:

\footnotetext{
${ }^{13}$ Como apontou Roland Barthes, a partir do momento em que a pessoa é olhada pela objetiva, tudo muda. Aproveitando as colocações de Barthes (1984: 26), a quem pertence a fotografia? Ao fotógrafo ou ao fotografado?
} 
A câmera em si tornou-se um importante meio de entrar na vida social da comunidade, permitindo-me participar em uma atividade compreensível para eles no decurso da observação. Meu ato de Tirar fotos fornecia aos moradores uma razão óbvia para iniciar uma conversa, e quanto mais fotografias eu fazia, mais pessoas eu conhecia (Schwartz, 1989: 125).

Assim como no relato de Schwartz, os moradores do baixo Araguari muitas vezes criavam expectativas quanto à minha visita e as fotos que eu poderia fazer sob demanda. Como em minha pesquisa de campo anterior, durante o mestrado (Stoeckli, 2011b), desenvolvi o hábito de devolver às pessoas retratadas as fotografias impressas.

Sobre as implicações de apreendermos um contexto através do enquadramento da câmera, um aspecto importante a ser observado é que a nossa percepção e interação com o espaço se modificam, pois no processo de produção de imagens limitamos ou sintonizamos nosso olhar ao que a câmera possibilita, o que inclui seus potenciais e limites. Dessa forma, ao emparelharmos o olhar com a câmera trazemos também enfoques diferentes do que teríamos com a atenção difusa, o que propicia uma atenção ampliada aos elementos visuais que ocorrem no espaço. No contexto da criação bubalina, a várzea amapaense e suas características comumente impõem distâncias significativas entre o observador e o observado. ${ }^{14}$

$\mathrm{Na}$ impossibilidade de aproximação de animais e, talvez de acompanhar os vaqueiros em certas práticas, as lentes fotográficas se mostram um forte aliado à observação de fenômenos importantes para a compreensão da cultura bubalina, sejam eles por parte dos animais ou dos humanos. Um episódio em específico se mostrou muito elucidativo sobre esse aspecto. Na ocasião eu acompanhava uma ação de laçada e vacinação de bezerros na Fazenda Helena Selva. Havia mais de dez vaqueiros vindos de fazendas adjacentes para "ajudar" o feitor Nonô. Toda a ação com o gado demorou a começar e por volta de meio-dia os animais já estavam mais estressados devido ao calor e excitação inerentes à lida em campos abertos e por meio de perseguição a cavalo.

\footnotetext{
${ }^{14}$ Como bem lembra Kirksey e Helmreich (2010: 547), é importante ter em mente que animais não são apenas bons para pensar ou se relacionar, eles podem também morder. No caso das fazendas dentro da Rebio e em seu entorno, alguns dos búfalos podem apresentar comportamento agressivo, em especial aqueles que ficam muito tempo sem contato com humanos ou aqueles que estão sendo perseguidos por vaqueiros.
} 


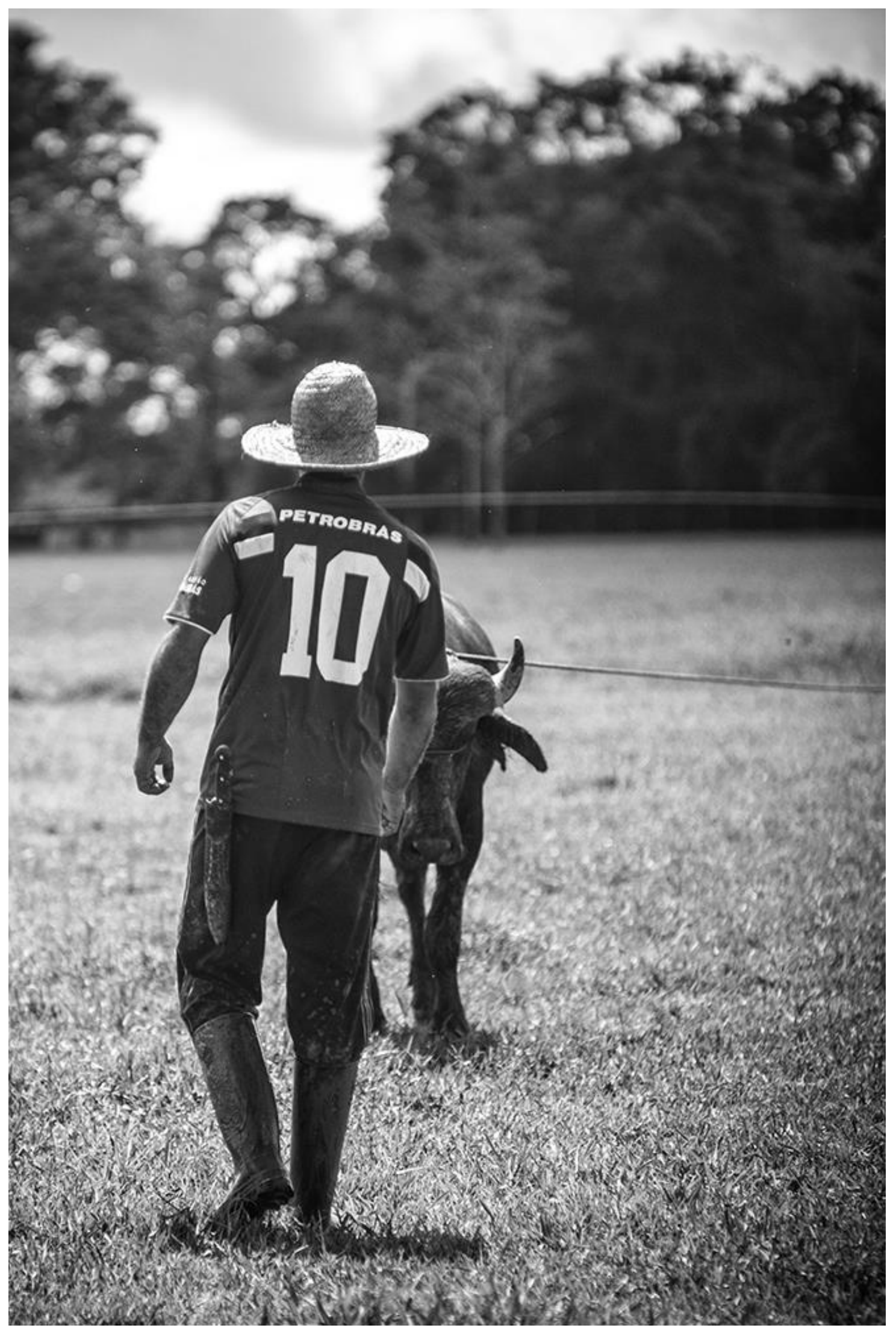

Figura 7: Vaqueiro encara um búfalo bravo. 
Eu acompanhava e fotografava os vaqueiros perseguindo os jovens búfalos e derrubando-os para a vacinação. Enquanto a maioria dos vaqueiros estava montada em cavalos, havendo apenas alguns "de pés" para auxiliar na derrubada do animal, eu não estava montado e me posicionei próximo a uma árvore grande com o intuito de minimamente me abrigar das "carreras" em que corriam o gado e os cavalos. Por isso, me vali de uma teleobjetiva para aproximar a visão de fotógrafo dos detalhes do acontecimento. Distraído com a visão limitada ao visor da câmera e da objetiva, ouvi um vaqueiro gritando com uma rês próxima de mim. Ambos o vaqueiro e o búfalo se posicionaram frente a frente por alguns momentos, como mostra a imagem acima.

$\mathrm{O}$ acontecimento foi relativamente rápido e durou poucos segundos, pois outros vaqueiros chegaram para continuar laçando a rês. Apesar de que o episódio me pareceu semelhante aos que eu já havia presenciado, ao mostrar as fotos para os vaqueiros mais tarde naquele mesmo dia (e nos dias vindouros), eles sempre paravam a sequência nessa imagem em específico e comentavam: "olha o boi bravo". Com pouco conhecimento sobre o comportamente dos búfalos, a cena em questão não me instigou uma interpretação específica. Mas ao ouvir essa observação que os próprios vaqueiros faziam da fotografia, passei a questioná-los por que eles sabiam que aquele boi estava bravo.

Dentre os aspectos apontados, estava o fato de que o búfalo estava virado para o vaqueiro com a cabeça erguida, comportamento atípico destes animais frente a alguém que está lhes laçando e derrubando. O mais comum é que uma rês volte seu corpo a uma posição de fuga, ou mesmo que fique somente com a cabeça abaixada. Ao verem o animal encarando um de seus colegas, os vaqueiros interepretavam seu comportamento e suas intenções, assim como o próprio búfalo interepretava o vaqueiro que ali lhe perseguia.

Nesse sentido, o reconhecimento visual mútuo é um elemento importante em contato no dia-a-dia entre animais e humanos que é desenvolvido e mantido por meio da prática cotidana. ${ }^{15}$ Vale aqui recorrer à concepção de Cristina Grasseni (2004: 46), que chama atenção ao fato de que na proposta da psicologia ecológica a "percepção visual é uma parte significativa da ligação ecológica entre um sujeito e seu meio ambiente, entendida tanto como o resultado de um processo ativo de exploração, quanto fonte de atividade perceptivamente guiada". Por isso, ao pesquisar um contexto como esse, o

\footnotetext{
${ }^{15}$ Em estudos sobre criadores de gado, como o de Grasseni (2004), Süssekind (2010) e Leal (2014), fica sempre explícita a predominância das relações de reconhecimento mútua entre os bovídeos e humanos.
} 
etnógrafo deve se esforçar em acompanhar as atividade em um processo de educação da atenção, uma busca ativa de informações no ambiente.

Em seu estudo sobre a percepção visual, James Gibson apresenta a proposta de uma ótica ecológica, em contraponto às óticas física, geométrica e fisiológica (Gibson, 1979). Embora o autor traga esse conceito para discutir diferenças entre luz e iluminação, por exemplo, creio que o termo pode ser compreendido dentro de sua teoria ampla de affordance também apresentada na mesma obra, conceito que se preocupa fundamentalmente com a questão de como se dá a percepção, uma realidade ecológica, em contraponto àquela descrita objetivamente pelas ciências duras.

Isso é dizer que uma pessoa nunca simplesmente olha, pois ela deve aprender como olhar, como se mover e como exercitar os sentidos em contextos específicos caracterizados pela prática (Mauss, 2003). Essa é a proposta de Grasseni (2004: 49), que afirma que a "visão habilidosa" (skilled vision, no original) é a maneira como o olhar pode ser treinado para detectar certas características específicas em objetos que estão normalmente disponíveis para a percepção generalizada, como as vacas.

Assim, o búfalo que encarava o vaqueiro de cabeça erguida demonstrava poder estar em um ataque iminente, situação perigosa e que o vaqueiro deve saber interpretar imediatamente, como aqueles que viam a fotografia faziam. Este fato fez com que me parecesse importante colocar esta imagem em destaque, por considerá-la etnograficamente muito rica ao me informar de todo um jogo de negociação sutil que me passou inicialmente despercebido.

Nessa reflexão, me parece pertinente seguir a concepção de Joana Scherer, que diz que o que classifica uma fotografia como etnográfica não é necessariamente a intenção de sua produção, mas a forma como ela é usada para informar etnograficamente os observadores (Scherer, 2003: 201). Para a autora, a metodologia para o uso de imagens fotográficas na pesquisa etnográfica inclui a análise detalhada em comparação com outras imagens, bem como o estudo das intenções e dos contextos em que os autores criaram as fotos (ibidem). Scherer ressalta, ainda, a necessidade do conhecimento de aspectos técnicos e de linguagem fotográficos. As reflexões de Scherer foram produzidas em um momento ${ }^{16}$ em que muito se advogava pela produção de imagens

\footnotetext{
${ }^{16}$ Notadamente, a publicação em que o artigo está inserido, Principles of Visual Anthropology (Hockings, 2003 [1974]) foi produzida a partir de um encontro ocorrido em Chicago ocorrido em 1973. A publicação contava também com artigos bastante citados de Margaret Mead e Jean Rouch, entre outros.
} 
etnográficas para fortalecer o potencial de comparação entre pesquisas feitas em contextos ou culturas semelhantes e contrastantes.

Na discussão sobre o uso de imagens como metodologia, é também importante citar a famosa análise imagética de Gregory Bateson e Margaret Mead Balinese Character (1942), um esforço único no histórico de produção visual etnográfica, tanto em termos de utilização de recursos ${ }^{17}$ quanto de inovação metodológica. Ao buscar em meios visuais uma maneira de retratarem o que consideravam difícil descrever, os autores propõem:

Por meio da utilização de fotografias, a totalidade de cada pedaço de comportamento pode ser preservada, enquanto a referência cruzada pretendida pode ser obtida ao inserirmos uma série de fotografias em uma mesma página (Bateson \& Mead, 1942: vii).

Essa é a proposição a partir da qual Bateson e Mead constroem suas análises em pranchas fotográficas, que inspirou o modo como dispus as imagens em minha tese. ${ }^{18}$ Como os próprios autores enfatizam (ibid.: 50), a seleção das imagens apresentadas em seu estudo eram guiadas por seu interesse na relação entre pais, filhos e parentes, como pode ser visto na famosa Prancha 47 (Stimulation and Frustration) em que uma mãe é representada proporcionando diferentes estímulos de afeto e negação do mesmo ao seu filho (Bateson \& Mead, 1942: 148-9).

No contexto de pesquisas sociais, considero ser importante ressaltar em que conjuntura de relações a imagem foi produzida. Pois fotografar é antes de tudo atribuir valor a um aspecto determinado de uma cena (Guran, 2012). É o alinhamento da cena com a visão do etnógrafo, o "eu estive lá" da autoridade etnográfica, ou, como diria Barthes (1984: 76), "a vidência do Fotógrafo não consiste em 'ver', mas em estar lá". Nesse sentido, a imagem feita durante uma etnografia é o posicionamento de um autor criando um discurso, ela lhe projeta para dentro da cena, uma situação de diretorpersonagem. Aquilo que uma pessoa fotografa está necessariamente em relação com ela.

\footnotetext{
${ }^{17}$ Segundo os próprios autores, Balinese Character foi composto por 759 fotografias, uma seleção resultante de cerca de 25000 negativos produzidos ao longo de dois anos de trabalho de campo (Bateson \& Mead, 1942: 49). É notável, também, o detalhamento técnico do material usado para a produção das imagens realizadas pelos autores, o que enfatiza o rigor metodológico de sua proposta (ibid.: 52).

${ }^{18}$ Margaret Mead comenta que a antropologia se consolidou como disciplina como uma "ciência de palavras", o que fez com que o uso de imagens como relato e reflexão etnográfica fosse deixada em segundo plano (2003: 5). Como um manifesto em favor da conjunção da etnografia e da produção visual, Mead afirma que o melhor trabalho é feito quando o filmmaker e o etnógrafo estão combinados em uma mesma pessoa, mesmo que em alguns casos uma habilidade se sobreponha à outra (ibid.: 7).
} 
E nisso o espectador é trazido à cena, um processo de visualização e interação dinâmica entre o fotógrafo e o espectador. Esse é o argumento de Dona Schwartz (1989: 122), para quem a imagem fotográfica tem uma natureza ambígua, pois o significado que ela assume depende também do processo de visualização feito pelo espectador. A fotografia, como outras obras visuais, organiza a informação de maneira a conduzir a experiência do espectador. Dentre os elementos de composição formal, um dos que mais tem importância para a construção da imagem é a relação do conteúdo com o seu frame, com o recorte que contém o conteúdo da cena retratada.

Sobre esse ponto, gostaria de citar as palavras de Luigi Ghirri (Ghirri, 2012: 56), para quem o apagamento do espaço que circunda a parte enquadrada é tão fundamental quanto o que é representado no frame: "e é graças a esse apagamento que a imagem assume sentido, tornando-se mensurável". Em um sentido semelhante, acredito que a noção de punctum apresentada por Barthes (1984) também contribui a esse assunto. Em seu texto, Barthes segue comentando fotografias para construir seu argumento, apontando, em algumas delas, a relação entre elementos que lhe chamam a atenção. Sem delimitar demasiadamente essa ideia, para não lhe tirar sua liberdade analítica, Barthes nos diz que "o punctum é, portanto, uma espécie de extracampo sutil, como se a imagem lançasse o desejo para além daquilo que ela dá a ver" (1984: 89).

Há relativamente pouco tempo, a decisão de trabalhar com cores ou com filme em preto-e-branco deveria ser feita antes da captura da imagem. Com o advento dos processos digitais, essa escolha pode ser posterior ao trabalho de campo, mas não deixa de ser significativa. $\mathrm{O}$ artifício de apresentar o mundo sem cor tanto remete à fotografia clássica quanto chama a atenção para aspectos centrais na imagem. ${ }^{19}$ Representar uma cena em preto, branco e tons de cinza é, em si, uma interpretação da realidade que estabelece um modo de relação com o que é fotografado. Esse é o caso também da escolha de objetivas com que se irá registrar o momento. ${ }^{20}$

Em relação a estes e outros aspectos estéticos da imagem, Bruce Barnbaum (2010) define que a boa composição é a maneira do artista de direcionar a visão do espectador de forma planejada. Assim, Barnbaum destaca pelo menos 14 elementos que definem a composição de uma fotografia. São eles:

\footnotetext{
${ }^{19}$ Barthes tem uma noção mais estrita sobre a produção de imagens em cores: “... sempre tenho a impressão (pouco importa o que realmente ocorre) de que (...) em toda fotografia, a cor é um revestimento aposto ulteriormente sobre a verdade original do Preto-e-Branco" (1984: 122).

${ }^{20}$ Lentes de longas distâncias focais (telefotos ou lentes semelhantes) tendem a comprimir o espaço, juntando objetos que estavam separados na cena. Lentes de distância focal curta (lentes grande angulares) tendem a exagerar o espaço, separando objetos que estavam, na realidade, muito próximos.
} 
1-Luz; 2-Cor; 3-Contraste; 4-Linhas; 5-Formas; 6-Padrões; 7-Equilíbrio; 8Movimento; 9-Espaço negativo e positivo; 10-Textura; 11-Posição da Câmera; 12 Distância Focal; 13-Profundidade de Campo; 14-Velocidade do obturador.

Além destes elementos elencados por Barnbaum, uma questão importante a ser pensada é a inserção da imagem dentro de uma série. Para alguns autores, o sentido da imagem surge quando ela é contrastada e ligada a outras: "Quanto mais fotos em uma sequência, mais autonomia elas ganham em sua trama interna, em suas repetições e em seus pontos mínimos de diferença" (Coelho, 2014). O ensaio fotográfico é, então, uma forma de trazer determinada ordem a um mundo não ordenado. É também um contraponto a trabalhos fragmentados, compostos de imagens isoladas. No caso da pesquisa de campo, é justamente a ênfase em algumas relações que o etnógrafo visa retratar que tornam a imagem relevante para se pensar determinado contexto.

É aqui que surge uma diferença entre fotografar sem interesses específicos e produzir imagens antropologicamente significativas. O tipo de relações com o contexto que a aproximação etnográfica empreendida exige nos leva a focar a nossa maneira de observar a relações entre seres, ambientes e elementos técnicos que, em princípio, guiam a maneira como as fotos são feitas. Esse princípio faz com que a imagem etnográfica não seja somente uma representação da cena fotografada, mas sim uma análise da mesma, pois guiam a atenção do espectador de modo a chamar sua atenção para alguns aspectos da cena retratada.

$\mathrm{Na}$ foto-título da tese baseada nesta pesquisa, "Laços Brutos", a imagem mostra um animal contido pela força física e as amarras do laço do vaqueiro. Tal congelamento não deixa de intrigar algumas questões, como o fato de que provavelmente a grande maioria dos animais que fotografei foram abatidos nos meses seguintes. "É a imagem viva de uma coisa morta", como diz Barthes (1984: 118), que afirma que esse potencial da imagem fotográfica pode levar à confusão entre o Real e o Vivo ao atestar que o que foi fotografado era real, o que induz a acreditarmos que é ainda vivo. ${ }^{21}$

\footnotetext{
21 "A fotografia, que nos mostra as coisas como se tivessem desaparecido e as criaturas como se estivessem mortas, é uma excelente iniciação ao véu de Maya" (Clair, 2011). Jean Clair trata aqui do que chama de uma metafísica da obra de Cartier-Bresson, ocupando-se da atemporalidade de seu trabalho. Contudo, essa frase em específico me levou a pensar o contexto em que fotografei, permeado de humanos, animais não-humanos e itens que intermediam a relação entre as partes. Devido à finalidade de produção da carne dos bubalinos, possivelmente a grande maioria, senão todos, os búfalos que fotografei estão atualmente mortos, consumidos.
} 
Ademais, nesta imagem em questão o enquadramento fotográfico também domina a cena, tornado o conjunto vaqueiro-laço-búfalo capturados pela lente do pesquisador. Isso me levou a refletir sobre por que escolhi compor a foto daquela maneira naquele momento e por que, em um momento posterior, a considerei etnograficamente representativa. De modo geral, o trabalho de edição e exibição da imagem é uma continuação do trabalho que começou no campo.

\section{Comentários finais}

Além da observação participante das atividades dos vaqueiros e das reuniões e discussões dos técnicos ambientalistas, parte considerável do que foi registrado e comentado na pesquisa foi mediado pela feitura e análise de imagens, fossem elas as imagens científicas apresentadas pelos ambientalistas ambientalistas, o trajeto do vaqueiro registrado pelo GPS, ou a imagem fotográfica de elementos da vaqueirice. Dessa forma, busquei amparar os argumentos desta pesquisa em registros visuais de práticas da cultura do búfalo.

Tal qual uma moldura que delimita a imagem fotográfica, a pesquisa etnográfica e a posterior reflexão teórica delimitam um universo dentre outros tantos possíveis. A inserção etnográfica em campo tem entre seus objetivos uma sensibilização do pesquisador para questões e momentos, comuns ou extraordinários, que ele presencia. Se é essencial à produção de conhecimento antropológico que o etnógrafo permaneça um tempo extenso em trabalho de campo, de modo a se sensibilizar a questões que antes lhe passavam despercebidas, acredito que um retorno à sequência das imagens produzidas pode demonstrar um aumento da presença do que foi fotografado àquilo que gradativamente foi se mostrando relevante ao estudo. Ocorre, então, um alinhamento da atenção etnográfica e fotográfica.

No processo de ordenação e apresentação da pesquisa de campo, acredito que existam paralelos entre a edição e inserção das imagens etnográficas e a reescrita dos dados coletados nos cadernos de campo, que são reorganizados para fazerem sentido para o público não familiarizado com o tema da pesquisa, um processo comparável a um segundo trabalho de campo, como bem apontou Strathern (1999). Assim, como etapa última e essencial de seu ofício, o etnógrafo/fotógrafo articula uma narrativa e uma realidade a serem apresentadas em seus relatórios sobre a pesquisa. E se desde os primeiros trabalhos antropológicos a produção de (e reflexão por) imagens marcou a 
disciplina, esta prática se mostra cada vez mais rica e refinada, o que continua a contribuir para o debate sobre os temas de interesse da antropologia.

\section{Agradecimentos}

Agradeço ao colega Fabiano Bachelany e ao professor Carlos E. Sautchuk pela discussão de alguns dos argumentos contidos neste texto.

\section{Referências}

BARNBAUM, Bruce. The Art of Photography: An Approach to Personal Expression. Santa Barbara: Rocky Nook, 2010.

BARTHES, Roland. A câmara clara: nota sobre a fotografia. Tradução: J. Castañon. Rio de Janeiro: Nova Fronteira, 1984 [1980].

BATESON, Gregory, e MEAD, Margaret. Balinese Character: a photographic analysis. New York: The New York Academy of Sciences, 1942.

BERT, Jean-François. Marcel Mauss et la notion de "civilisation". Cahiers de recherche sociologique , n. 47, p. 123-142, 2009.

BISAGGIO, Eduardo, ALVES, Sandro L., SANTOS JÚNIOR, Celso Costa, e BARRA ROCHA, Cézar Henrique. Búfalos Ferais (Bubalus bubalis) em Áreas Protegidas: um estudo de caso na Reserva Biológica do Guaporé, RO. Biodiversidade Brasileira, v.3, n. 2, p. 243-260, 2013.

BRASIL. Lei 9.985, de 18 de julho de 2000. Regulamenta o art. 225, § $1^{\circ}$, incisos I, II, III, e VII da Constituição Federal, institui o Sistema Nacional de Unidades de Conservação da Natureza e dá outras providências. Diário Oficial da União. Seção 1, p.1, 19/07/2000.

CLAIR, Jean. Introdução a uma pequena metafísica da fotografia acerca da obra de Henri Cartier-Bresson. In: Henri Cartier-Bresson. São Paulo: Cosac \& Naify, 2011.

COELHO, Frederico. Ver com olhos livres. Zum n. 6, p. 11-14, 2014.

COLLIER et al. Turning Pests into Profits: Introduced Buffalo Provide Multiple Benefits to Indigenous People of Northern Australia. Human Ecology, v. 39, p. 155-164, 2011.

DANIEL, Zarin et al. Landscape change in tidal floodplains near the mouth of the Amazon River. In: Forest Ecology and Management, v. 154, p. 383-393, 2001.

GEERTZ, Clifford. Thick Description: Toward an Interpretative Theory of Cultura. In: Clifford Geertz. The Interpretation of Cultures. New York: Basic Books, 1973. P. 3-33. GHIRRI, Luigi. Kodachrome. Zum, n. 3, 2012 [1978].

GIBSON, James. The ecological approach to visual perception. Boston: Houghton Mifflin, 1979.

GRASSENI, Cristina. Skilled vision. An apprenticeship in breeding aesthetics. Social Anthropology. v. 12, n. 1, p. 41-55, 2004.

GURAN, Milton. Fotografar para descobrir, fotografar para contar: a fotografia como instrumento de pesquisa (Apresentação Oral). 2012.

HADRICOURT, André-Georges, e P. DIBIE. Que Savons-nous des animaux domestiques? L'Homme, tome 28 n. 108, p. 72-83, 1988. 
HOCKINGS, Paul (ed.). Principles of Visual Anthropology. Berlin/ New York: Mouton de Gruyter. 2003[1974].

IBAMA. Roteiro metodológico para a gestão de Parque nacional, Reserva Biológica, Estação Ecológica. Brasília: IBAMA, 2002.

INGOLD, Tim. Humanity and Animality. In: Tim Ingold, Companion Encyclopedia of Anthropology. Londres: Routledge, 1994. pp. 14-32.

INGOLD, Tim. The Perception of the Environment: Essays on Livelihood, dwelling and skill. London: Routledge, 2000.

KOHN, Eduardo. How dogs dream: Amazonian Natures and the Politics of Transspecies Engagement. American Ethnologist, v. 34, n. 1, p. 3-24, 2007.

LATOUR, Bruno. Referência circulante: amostragem do solo da floresta Amazônica. In: LATOUR, Bruno. A esperaça de Pandora: ensaios sobre a realidade dos estudos científicos. Bauru: EDUSC, p. 39-98, 2001.

LEAL, Natacha. Nome aos Bois: Zebus e zebuzeiros em uma pecuária brasileira de elite. 2014. Tese (Doutorado em Antropologia Social) - Programa de Pós-Graduação em Antropologia Social, Universidade de São Paulo, São Paulo.

MALINOWSKI, Bronislaw. Argonautas do Pacífico Ocidental. São Paulo: Abril Cultural, 1976 [1922].

MARQUES, J. R. F. Búfalos: o produtor pergunta, a Embrapa responde. Brasília: Embrapa, 2000.

MARQUES, José Ribamar Felipe; LOPES, César Augusto Carneiro; MARTINEZ, Gladys Beatriz. Produção animal nas vázeas do Rio Amazonas. 359. Belém: Embrapa Amazônia Oriental, 2003.

MAUSS, Marcel. As técnicas do corpo." In: MAUSS, Marcel. Sociologia $e$ Antropologia. Tradução: Paulo Neves. São Paulo: Cosac \& Naify, 2003. Pp. 399-424.

MEAD, Margaret. Visual Anthropology in a Discipline of Words. In: HOCKINGS, Paul (ed.). Principles of Visual Anthropology. New York: Mouton de Gruyter, p. 3-12, 2003 [1974].

MINISTÉRIO DO MEIO AMBIENTE. Atlas das Unidades de Conservação do Estado do Amapá. Macapá: MMA/IBAMA-AP; GEA/SEMA, 2008.

MONTEIRO, Fred J. C. Impactos ambientais causados pelos búfalos asselvajados nos campos inundáveis da Estação Ecológica de Maracá Jipioca (Costa Atlântica do Amapá). 2009. Dissertação (Mestrado em Biodiversidade Tropical) - Programa de Pósgraduação em Biodiversidade Tropical, Fundacao Universidade do Amapa, Macapá: UNIFAP, 2009.

RAFFLES, Hugh. In Amazonia: A Natural History. Princeton: Princeton University Press, 2002.

ROUCH, Jean. The Camera and Man. In: HOCKINGS, Paul (Ed.). Principles of Visual Anthropology. New York: Mouton de Gruyter, p. 79-98, 2003[1974].

SAMAIN, Etienne (Org.). O fotográfico. São Paulo: HUCITEC/CNPq, 1998.

SANTOS, Valdenira Ferreira dos. Ambientes Costeiros Amazônicos: Avaliação de Modificações por Sensoriamento Remoto. 2006. Tese (Doutorado em Geologia e Geofísica Marinha) - Programa de Pós-graduação em Geologia e Geofísica Marinha, Universidade Federal Fluminense, Niterói.

SAUTCHUK, Carlos E. Cine-weapon: The poiesis of filming and fishing. Vibrant Virtual Brazilian Anthropology v. 9, n. 2 (ABA), p. 407-430, 2012.

SAUTCHUK, Carlos E. O Arpão e o Anzol - técnica e pessoa no estuário do Amazonas (Vila Sucuriju, Amapá). 2007. Tese (Doutorado em . Antropologia Social) - Programa de Pos-graduação em Antropologia Social, Universidade de Brasília, Brasília. 
SCHERER, Joanna Cohan. Ethnographic Photography in Anthropological Research. In: HOCKINGS, Paul (Ed.). Principles of Visual Anthropology. New York: Mouton de Gruyter, p. 201-216, 2003[1974].

SCHWARTZ, Dona. Visual Ethnography: Using Photography in Qualitative Research." Qualitative Sociology, v. 12, n. 2 (Human Sciences Press), p. 119-154, 1989.

SEEGER, Anthony. Pesquisa de Campo: uma criança no mundo. In: SEEGER, Anthony. Os indios e nós: estudos sobre sociedades tribais brasileiras. Rio de Janeiro: Campus, p. 25-42, 1980.

STOECKLI, Pedro. "Comentário sobre o processo fílmico e fotográfico na pesquisa de campo.” $R @ U$ v. 3 (PPGAS/UFSCAR), p. 393-403, 2011 a.

STOECKLI, Pedro. Sobre mestres e encantados: a jurema como expressão sentimental. 2011b. Dissertação (Mestrado em Antropologia Social) - Programa de Pos-graduação em Antropologia Social, Universidade de Brasília, Brasília.

STRATHERN, Marilyn. The Ethnographic Effect I. In: STRATHERN, Marilyn. Property, substance, and effect: anthropological essays on persons and things. New York: The Athlone Press, p. 1-29, 1999.

SÜSSEKIND, Felipe. O Rastro da Onça: Etnografia de um projeto de conservação em fazendas de gado do Pantanal Sul. 2010. Tese (Doutorado em Antropologia Social) Museu Nacional, Universidade Federal do Rio de Janeiro, Rio de Janeiro.

TOMÁS, M.W., Liliani Maria TIEPOLO, CAMILO, Ana Rosa. Relatório Técnico Estimativa do tamanho da população e distribuição de búfalos (Bubalus bubalis) asselvajados e domésticos na REBIO do Lago Piratuba e na Estação Ecológica de Maracá-Jipióca. IBAMA, p.16, 2007.

UEXKÜLL, Thure von. A teoria da Umwelt de Jakob von Uexküll. Galáxia, n. 7, 2004: p. 19-48, 2004.

Recebido em: 16/11/2015.

Aprovado em: 24/12/2015. 